\title{
OSHA AND THE EXCLUSIONARY RULE: SHOULD THE EMPLOYER GO FREE BECAUSE THE COMPLIANCE OFFICER HAS BLUNDERED?
}

\author{
Charles E. TRANT*
}

One of the strongest grievances our forefathers articulated in the Declaration of Independence was that the King had "sent hither swarms of Officers to harrass our People . . . ."l Perhaps they would have been surprised that some two hundred years later this coinplaint would arise again, this time from employers criticizing the United States government for the "swarms" of coinpliance officers sent under the Occupational Safety and Health Act ${ }^{2}$ (the Act) to "harrass" them. The use of officers to execute general warrants and writs of assistance was a catalyst of the American Revolution. ${ }^{3}$ This distasteful experience was directly responsible for the inclusion of the fourth amendment right to be free froin unreasonable searches and seizures ${ }^{4}$ in the Bill of Rights. Despite its modest appearance, the fourth amendment is deceptively complex, possessing "both the virtue of brevity and the vice of ambiguity."s It neither defines "unreasonable" nor enumerates any sanctions for its violation. Left to their own devices, the courts filled this gap, at least in criminal cases, by developing an "exclusionary rule"6 which prohibits the introduction of evidence obtained in a

* Captain, Judge Advocate General Corps, United States Army. A.B. 1973, Suffolk University; J.D. 1975, Suffolk University Law School; L.L.M. 1981, Georgetown University Law Center.

1. U.S. DeCLARATION OF INDEPENDENCE.

2. 29 U.S.C. $\$ \S 651-678$ (1976).

3. Dickenson, Writs of Assistance as a Cause of the Revolution, in THE ERA OF THE AMERICAN Revolution 40-75 (R. Morris ed. 1939).

4. The fourth amendment provides:

The right of the people to be secure in their persons, houses, papers, and effects, against unreasonable searches and seizures, shall not be violated, and no Warrants shall issue, but upon probable cause, supported by Oath or affirmation, and particularly describing the place to be searched, and the persons or things to be seized.

U.S. CoNST. ainend. IV.

5. J. Landynski, Search and Seizure and the Supreme Court 42 (1966).

6. The "rule" is really a "sanction"; a rule imples an affirmative obligation of conphiance while a sanction signifies a remedy flowing fron a violation of the substantive nuandate of the anendment. Additionally, Dean McCormick reminds us that exclusionary rules "nuay be classified as privileges rather than as rules of incompetency, as they are designed to protect interests deemed of great social importance rather than to guard against evidence which is unrehiable or 
search violative of the fourth amendment. ${ }^{7}$ The applicability of the fourth amendment to administrative searches has undergone a turbulent reexamination in the last fifteen years. ${ }^{8}$ In Marshall v. Barlow's, Inc. ${ }^{9}$ the Supreme Court established the fourth amendment's applicability to Occupational Safety and Health Administration (OSHA) imspections. ${ }^{10}$ The Court left unanswered, however, the extent to which the exclusionary sanction must be applied to OSHA inspections and what suitable alternative remedies would exist if the sanction were not applied.

This article considers the propriety of applying the exclusionary rule in OSHA proceedings. It examines the purpose of the exclusionary rule in administrative search law, the nature of OSHA hearings and penalties, and the relevant policy concerns. The article concludes that application of the exclusionary sanction in OSHA proceedings is appropriate because its application preserves employers' fourtl ainendment rights without hindering the fulfillment of the goals of the Act.

\section{Development of Administrative Search LaW}

The primary goal of modern health, safety, samitation, and housing regulations is to prevent or correct undesirable conditions. Agencies created to enforce these regulations, sucli as OSHA, nnust rely on administrative inspections as their primary method of acquiring information. Indeed, agency inspections affect so many aspects of our existence, ranging from inspections of autornobiles ${ }^{11}$ to inspections of food, ${ }^{12}$ that they have become an accepted part of life. Businessmen,

calculated to prejudice or mislead the trier of fact." C. MCCORMICK, HANDBOOK ON THE LAW OF EVIDENCE 365 (2d ed. 1972).

7. The rule was first stated in Weeks v. United States, 232 U.S. 383 (1914). This sanction is not absolute. See, e.g., Rawlings v. Kentucky, 448 U.S. 98 (1980) (defeudant lacks standing to assert unlawful search of another person's property); Walder v. United States, 347 U.S. 62 (1954) (unlawfully seized evidence inay be used to impeach defendant's testimony). See generally Coinmeut, The Impeachment Exception to the Exclusionary Rules, 34 U. CHI. L. REv. 939 (1967).

8. Compare Camara v. Municipal Court, 387 U.S. 523 (1968) and See v. City of Seattle, 387 U.S. 541 (1968) with United States v. Biswell, 406 U.S. 311 (1972) and Colormade Catering Corp. v. United States, 397 U.S. 72 (1970).

9. 436 U.S. 307 (1978).

10. See Note, Marshall v. Barlow's, Inc.: Are Employer's Fourth Amendment Rights Protected?, 16 CAL. W.L. REv. 161 (1980); Note, The Search Warrant Requirement for OSHA Inspections: Upholding Business Owner's Fourth Amendment Rights-Marshall v. Barlow's, Inc., 28 DePaul L. Rev. 105 (1978).

11. See Delaware v. Prouse, 440 U.S. 648, 658 (1979). See also State v. Burns, 591 P.2d 563 (Ariz. App. 1979).

12. See, e.g., United States v. Thriftimart, Inc., 429 F.2d 1006 (9th Cir. 1970). See generally Norton, The Constitutionality of Warrantless Inspections by the Food and Drug Administration, 35 FOOD DRUG COSM. L.J. 25 (1980). 
for example, have long been subject to inspection of their premises to detect building code violations, ${ }^{13}$ but the creation of OSHA expanded dramatically the scope and diversity of these inspections. The development of administrative search law and the fourth amendment's peculiar application to this kind of law are necessary starting points in addressing the desirability of applying the exclusionary sanction to Occupational Health and Safety Review Commission (OSHRC) hearings.

The application of admimistrative search law to businesses evolved as a judicial response to fill a gap created by the language of the fourth amendment, which specifically applies only to "persons, houses, papers, and effects." 14 The Supreme Court has made clear that criminal searches of businesses are within the protections of the fourth amendinent. ${ }^{15}$ The status of the law, however, concerning the "civil inspection" and the warrantless search of homes or businesses is inuch less certam. ${ }^{16}$ Indicative of early warrantless "civil inspection" law is Frank v. Maryland, ${ }^{17}$ where a state criminal conviction based on a warrantless inspection by a city health inspector was appealed to the Supreme Court. Recognizing that the fourth amendinent prohibits only "unreasonable" searches, ${ }^{18}$ the Court suggested a balancing test to determine the reasonableness of the search. The Court concluded that the societal interest in maintaining a healthy environment outweighed the individual interest in privacy. The determinative considerations were that the inspection was inerely for the purpose of ascertaining whether health violations existed, not for the purpose of seizing criminal evidence; that the search was conducted at a reasonable time in a reasonable manner;

13. See, e.g., Euge v. Trantina, 298 F. Supp. 873, 875 (E.D. Mo. 1969), affd, 422 F.2d 1070 (8th Cir. 1970). See generally LaFave, Search and Seizure: A Treatise on the Fourth AMENDMENT \& 10.2 (1978).

14. This choice of words was curious because the general warrants and writs of assistance that resulted in the dissatisfaction responsible for the fourth amendment were directed primarily at business establishments. See N. LASsON, supra note 5, at 137-39. Perhaps the term "effects" was ineant to include business establishments.

15. See, e.g., Silverthorne Lumber Co. v. United States, 251 U.S. 385 (1920). See also GoBart Inporting Co. v. United States, 282 U.S. 344 (1931); Amos v. United States, 255 U.S. 313 (1921).

16. The Supreine Court has noted that its decisions "dealing with the constitutionality of warrantless searches ... suggest that this branch of the law is something less than a seamless web." Cady v. Dumbrowski, 413 U.S. 433, 440 (1973).

17. 359 U.S. 360 (1959).

18. Amoug the complexities of the fourth amendment is the use of the conjunction "and" between the "unreasonable searches" clause and the "warrant" clause. It is still unresolved whether the two clauses are independent prohibitions or whether the clauses nnust be read as an entirety. The first view finds support in Boyd v. United States, 116 U.S. 616, 638-41 (1886) (Miller, J., concurring), and the second finds support in Almeida-Sanchez v. United States, 413 U.S. 266, 277 (1973) (Powell, J., concurring). 
and that valid grounds existed for suspicion of healtl violations. ${ }^{19}$ The Court found that the asserted individual privacy interest was, at most, on the "periphery" of the fourtl amendinent. 20 Thus, Frank enunciated the Court's policy of refusing to apply a warrant requirement to a civil search.

Insofar as Frank approved warrantless inspections, it was overruled by Camara v. Municipal Court ${ }^{21}$ and See v. City of Seattle, ${ }^{22}$ compamion cases which held that the warrant clause of the fourth amendment applies to administrative searclies. ${ }^{23}$ Camara rejected the notion that an imdividual's privacy imterest is only "peripheral" and declared that administrative searclies involved a "significant intrusion" upon this interest. ${ }^{24}$ The Court's premise was that the constitutionally mandated standard for administrative searches is "reasonableness." Because wliat is reasonable in the criminal context is not necessarily reasonable in the administrative context, the Court created an administrative probable cause standard, which is less stringent than the criminal probable cause standard, ${ }^{25}$ for the issuance of administrative search warrants.

In administrative cases the magistrate unust balance the public interest against the intrusion upon the privacy interest to determine the reasonableness of the search. ${ }^{26}$ The nature of the premises sought to be inspected is an important variable in this equation. The individual's

19. 359 U.S. at 366.

20. Id. at 367 . The criticism of the "priority of interests" approach was immediate, as evidenced by Justice Douglas's dissent which stated, inter alia, that: " To say that a man suspected of crime has a right to protection against searches of his home without a warrant, but that a man not suspected of crime has no such protection, is a fantastic absurdity." " 359 U.S. at 378 (Douglas, J., dissenting) (citing District of Columbia v. Little, 178 F.2d 13, 16-17 (D.C. Cir.), affd on other grounds, 339 U.S. 1 (1950)).

21. 387 U.S. 523 (1968).

22. 387 U.S. 541 (1968).

23. In Camara the Court noted: "It is surely anomalous to say that the individual and his private property are fully protected by the Fourth Amendment only when the individual is suspected of criminal behavior." 387 U.S. at 530 . This portion of the opinion rephrases Justice Douglas's dissent in Frank. See note 20 supra. For a discussion of these cases, see LaFave, $A d$ ministrative Searches and the Fourth Amendment: The Camara and See Cases, 1967 SUP. CT. REv. 1.

24. 387 U.S. at 534.

25. This diluted standard has been criticized as "synthetic probable cause." It blurs the crimmal/civil dichotomy by applying the fourth amendent to civil searches with a lesser probable cause standard. Justice Clark declared in See that this "newfangled 'warrant' system" prostitutes the commands of the fourth amendment. 387 U.S. at 547 (Clark, J., dissenting).

26. See Greenburg, The Balance of Interests Theory and the Fourth Amendment: A Selective Analysis of Supreme Court Action Since Camara and Sce, 61 Calif. L. Rev. 1011 (1973). "A balance of interests approach, then theoretically demands a sliding scale of probability standard, varying with the level of intrusion in each type of situation." Id 1016. 
privacy interest is far greater in his residence than in his place of business, ${ }^{27}$ but no greater, theoretically, in a criminal search than in a civil inspection. The public interest varies substantially depending on the purpose of the search. ${ }^{28}$ Because of these differences, the application of the balance-of-interests theory to a inultiplicity of situations has led to its reevaluation and refinement.

A number of recognized exceptions exist to the warrant requirement established by Camara and See. Generally, no warrant is necessary in emergency situations, ${ }^{29}$ when there has been consent to the search, ${ }^{30}$ or when the premises are in open view. ${ }^{31}$ The strongest challenge to the Camara-See balance of interests doctrine came in the licensed business cases, ${ }^{32}$ in which the courts based their deviation from the warrant requirement on an "implied consent" theory. ${ }^{33}$ These decisions appeared to weaken Camara and $S e e,{ }^{34}$ but the Supreme Court arrested this erosion in Air Pollution Variance Board $v$. Western Alfalfa Corp. ${ }^{35}$ which involved an entry upon business premises by a pollution control officer who did not possess a warrant. Although the case ultimately was decided on the "open view" rationale, the Court expressly affirmed Camara and See. ${ }^{36}$

During the period of reappraisal of the Camara and See doctrine, OSHA entered the field of administrative search law. Warrantless in-

27. In Camara the premises were residential, but the Court noted: "We do not in any way imply that business premises may not reasonably be inspected in many more situatious than private homes . . . "387 U.S. at 545-46.

28. One commentator has suggested that the privacy interest is constant and absolute, and that the governmental interest is the variable in the equation. Comment, The Warrant Requirement for OSHA Inspections: The Supreme Court Establishes a Two-Tiered Test for Probable Cause, 15 Willametre L. Rev. 61, 79-83 (1978). See also Greenburg, supra note 26, at 1046-47.

29. 387 U.S. at 539. See, e.g., United States v. Gargotto, 510 F.2d 409 (6th Cir.), cert. denied, 421 U.S. 987 (1974). See generally Note, The Emergency Doctrine, Civil Search and Seizure, and the Fourth Amendment, 43 FORDHAM L. REv. 571 (1975).

30. 387 U.S. at 545 . Most businessmen willingly consent to administrative inspections. See United States v. Thriftimart, Inc., 429 F.2d 1006, 1009 (9th Cir.), cert. denied, 400 U.S. 926 (1970).

31. See Air Pollution Variance Bd. v. Western Alfalfa Corp., 416 U.S. 861 (1974).

32. See, e.g., United States v. Biswell, 406 U.S. 311 (1972) (pawnshop permit); Colonnade Catering Corp. v. United States, 397 U.S. 72 (1970) (liquor hicense).

33. See Almeida-Sanchez v. United States, 413 U.S. 266, 271 (1973). The Court extended the implied consent concept to visits by caseworkers to the homes of recipients of public assistance in Wyman v. James, 400 U.S. 309 (1971). Balancing the recipient's privacy interest against the public interest in protecting the dependent child, the Court found no constitutional violation. Id. at 326.

34. Sce, eg., Note, The Law of Administrative Inspections: Are Camara and See Still Alive and Well?, 1972 WASH. U.L.Q. 313.

35. 416 U.S. 861 (1974).

36. Id. at 864. This decision is significant for OSHA purposes because it concerned an administrative inspection conducted for the purpose of pronioting health and safety. For its inpact on Camara and See, see Almeida-Sanchez v. United States, 413 U.S. 266 (1973). 
spections by OSHA compliance officers immediately generated controversy. ${ }^{37}$ The breadth and pervasiveness of the Act requires imspections, as its purposes and policies cannot be fulfilled if compliance officers have to depend solely on employee complaints and voluntary compliance by einployers. ${ }^{38}$ Early judicial review of OSHA warrantless inspections revealed a sharp difference of opinion about whether the licensed business cases actually narrowed Camara and See or inerely created exceptions to the warrant requirement. 39

In Marshall v. Barlow's, Inc. ${ }^{40}$ however, the Supreme Court upheld the conclusion of a three-judge district court ${ }^{41}$ that the warrant requirement of the fourth amendment applies to OSHA imspections. ${ }^{42}$ The Court rejected the argument of the Secretary of Labor that OSHA inspections fall within the recognized exceptions for licensed or closelyregulated businesses and industries established in United States v. Bis-

37. See generally Comment, OSHA v. The Fourth Amendment: Should Search Warrants Be Required for "Spot Check" Inspections?, 29 BAYLOR L. Rev. 283 (1977); Comment, The Validity' of Warrantless Searches Under the Occupational Safety and Health Act of 1970, 44 CIN. L. REv. 105 (1975).

38. Representative Steiger, the principal proponent of the Act, stated: "[I]t is important to note that warrantless civil inspections are both absolutely essential to this Act's enforcement and a longstanding Federal Practice." 123 CoNG. REC. 325 (1977) (reinarks of Rep. Steiger).

Thus, the Act provides:

In order to carry out the purposes of this chapter, the Secretary, upon presenting appropriate credentials to the owner, operator, or agent in charge, is authorized-(1) to enter without delay and at reasonable times any factory, plant, establishment, construction site, or other area, workplace or environment where work is perforined by an employee of an einployer, and (2) to inspect and investigate during regular working hours and at other reasonable times and within reasonable limits and in a reasonable manner, any such place of einployment and all pertiment conditions, structures, machimes, apparatus, devices, equipinent, and materials therem, and to question privately any sucli employer, owner, operator, agent or employce.

29 U.S.C. \& 657 (1976). Significantly absent from this authorization, however, is language which specifically provides for warrantless inspections. Such language does appear in other federal labor legislation. See, e.g., Fair Labor Standards Act, 29 U.S.C. \$211(a) (1976); Coal Mine Health and Safety Act, 30 U.S.C. $\$ 813$ (1976).

39. In two cases factually similar to Marshall v. Barlow's, Inc., 436 U.S. 307 (1978), the courts came to opposite conclusions on the warrant issue. Compare Brennan v. Buckeye Indus., $374 \mathrm{~F}$. Supp. 1350 (S.D. Ga. 1974) (no warrant required) with Brennan v. Gibson's Products, Inc., 407 F. Supp. 154 (E.D. Tex. 1976) (warrant required) vacated, Marshall v. Gibson's Prods, Inc., 584 F.2d 668 (Sth Cir. 1978). See generally Comment, Brennan v. Buckeye Industries, Inc. : The Constitutionality of an OSHA Warrantless Search, 1975 DUKE L.J. 406; Note, OSHA Inspections and the Fourth Amendment: Balancing Private Rights and Public Need, 6 FORDHAM URB. L.J. 101 (1977).

40. 436 U.S. 307 (1978).

41. Barlow's, Inc. v. Usery, 424 F. Supp. 437 (D. Idaho 1977), affd sub nom. Marslaall v. Barlow's, Inc., 436 U.S. 307 (1978), held the general warrantless inspection (not pursuant to an employee complaint) violative of the fourth ainendment, stating that " 'except in certain carefully defined classes of cases, the search of private property without proper consent is "unreasonable" unless it has been authorized by a valid search warrant." 424 F. Supp. at 440 (quotimg Camara v. Municipal Court, 387 U.S. 523, 529 (1967)).

42. 436 U.S. at 312-13. 
well ${ }^{43}$ and Colonnade Catering Corp. v. United States. ${ }^{44}$ The Court reaffirmed the vitality of Camara and See by adopting the approach of balancing the public interest against the individual privacy interest, the underlying standard being one of reasonableness. ${ }^{45}$ This balancing results in a warrant requirement for OSHA inspections, but the warrant can be based on the administrative probable cause standard first enunciated in Camara. ${ }^{46}$ Because of the additional protections afforded businessinen by a warrant, the Court behieved that this flexible probable cause standard reasonably balanced the interests involved and that it would not undermine the government's ability to effectuate the purposes and policies of the Act. ${ }^{47}$ The Court provided Barlow's with a "declaratory judgment that the Act is unconstitutional insofar as it purports to authorize inspections without warrant or its equivalent and [with] an mjunction enjoining the Act's enforcement to that extent."48 Because no inspection ever occurred im Barlow's, no fruits of a warrantless search could be objected to at an OSHRC hearing. Barlow's thus clarified when an OSHA imspection violates the fourth amendment, but did not reach the issue of what sanction, if any, applies when an unlawful inspection occurs. Thus, the applicability of the exclusionary rule in OSHA proceedimgs is uncertain.

43. 406 U.S. 311 (1972).

44. 397 U.S. 72 (1970); see 436 U.S. at 313-14. The court refused to extend to ordinary businesses the legal fictiou of "implied consent" that it had applied to licensed businesses. The mere fact that a business lias some effect on interstate commerce does not result in "implied consent" to warrantless inspections. Id. For a discussion of Biswell and Colonnade Catering, see notes 32-34 supra and accoinpanying text.

45. A search is presumptively unreasonable without a warrant. 436 U.S. at 313 (citing Camara v. Mumicipal Court, 387 U.S. 523, 528-29 (1968)).

46. The Court described the less strict standard as follows:

For purposes of an administrative search sucl as this, probable cause justifying the issuance of a warrant may be based not only on specific evidence of an existing violation but also on a showing that "reasonable legislative or administrative standards for conducting an . . . inspection are satisfied with respect to a particnlar [establishment]."

436 U.S. at 320-21 (quoting Camara v. Mumcipal Court, 387 U.S. at 538) (footnote ouritted).

47. 436 U.S. at 320-21. The Court did not consider the additional financial and nnanpower burdens to be significant and suggested that the administrative efficiency of OSHA inspections could be maintamed by ex parte warrants based on the flexible probable cause standard. Id. See Stoddard Lunber Co. v. Marsliall, 627 F.2d 984 (9th Cir. 1980); Marsliall v. W \& W Steel Co., 604 F.2d 1322 (10th Cir. 1979). But see Cerro Metal Products v. Marshall, 620 F.2d 964 (3d Cir. 1980).

Justice Stevens, disseuting in Camara, stated that "the warrant is essentially a formality," 436 U.S. at 334, and that the slight additional protection or benefit it might provide does not "justify overriding Cougress's judgment that the power to conduct warrantless inspections is essential." Id. at 332 .

48. Id. at 325 (footnote omitted). 


\section{Development of the Exclusionary Rule}

One cannot assess whether an exclusionary rule is constitutionally required or even desirable as a matter of social policy without understanding the history of its development. ${ }^{49}$ The precursor of the rule appeared as dictum in Boyd $v$. United States, ${ }^{50}$ which mvolved an action for forfeiture of goods allegedly illegally imported. The district court had granted a Government motion compelling the defendants to produce an invoice froin their records, which the defendants had done under protest. The Supreme Court concluded that this forced production of papers was a "search" and that the proscriptions of the fourth amendment applied because of the "quasi-criminal nature" of the proceeding. ${ }^{51}$ The Court stated that the admission at the trial of the invoice as evidence was "erroneous and unconstitutional." 52

This holding ran contrary to the prevalent common law rule that if evidence was otherwise admissible a court would not inquire into the means by which the proponent of the evidence had acquired it. ${ }^{53}$ The common law rule, however, survived Boyd. In Adams v. New York ${ }^{54}$ the Supreme Court stated that in a criminal case a collateral issue could not be raised about the source of otherwise competent testimony. ${ }^{55}$

Not until twenty-eight years after Boyd, in Weeks v. United States, ${ }^{56}$ an appeal of a federal conviction for using the mails to transmit lottery tickets, did the exclusionary rule emerge. ${ }^{57}$ In Weeks the Court voiced concern that, absent some restriction on the use of the fruits of illegal searches and seizures, fourth amendment guaranties would be nullities..$^{58}$ The Court also sought to protect judicial integrity by refusing to sanction convictions gained ${ }^{-}$by illegal searches and

49. See generally $\mathrm{W}$. LAFave, Search and SeIzURE: A Treatise on the Fourth AMENDMENT \& 1.1(a)-(e) (1978).

50. 116 U.S. 616 (1886).

51. Id. at 637-38. The Court's conclusions about the applicability of the fourth amendment are somewhat blurred by a creative intertwining of the fourth and fifth amendments.

52. Id. at 638.

53. See cases cited in Adams v. New York, 192 U.S. 585, 595-96 (1904).

54. 192 U.S. 585 (1904).

55. Id. at 595. The Court noted that this rule had been adopted by so many state courts that it was impractical to cite thein all.

56. 232 U.S. 383 (1914).

57. Two warrantless searches were involved in this case. State officials conducted one search, and they turned their evidence over to federal officials. The federal officials later conducted a second search. The Court had no difficulty in sustaining the admission of the evidence obtained in the state officials' search, concluding that the fourth amendment did not apply to those officials. Id. at 398.

58. The Court stated:

If letters and private documents can thus be seized and held and used in evidence. . . the protection of the Fourth Amendment declaring his right to be secure agaimst such 
seizures. ${ }^{59}$ This concern for judicial integrity was central to the Court's rationale for fashioning an exclusionary rule applicable to federal officers.

In extending this rationale and the exclusionary rule to state officials, tlie court had to determine first whether the fourtli amendment apphed to the states by incorporation into the fourteenth amendment, ${ }^{60}$ and, if so, whether tlie exclusionary sanction sliould apply to tlie states. In Wolf $v$. Colorado ${ }^{61}$ the Court focused precisely on this issue, ${ }^{62}$ holdmg that the proscriptions of the fourth amendment applied to the states, ${ }^{63}$ but that "the ways of enforcing sucli a basic right raise questions of a different order."64 The Court refused to extend tlie exclusionary rule to state proceedimgs, leavimg the victims of illegal state searches to other remedies sucli as private causes of action and internal-police disciplinary procedures. ${ }^{65}$ Stating that the exclusionary rule is not required by the fourth amendment, the Court refused to extend the rule because it liad been created only as "a matter of judicial

searches and seizures is of no value, and, so far as those thus placed are concerned, might as well be stricken from the Constitution.

232 U.S. at 393 (Day, J.).

59. The Court noted that the tendency of those who enforce the criminal laws of the country to obtain convictions by means of unlawful seizures should not be condoned. To do so "would be to affirm by judicial decision a manifest neglect if not an open defiance of the prohibitions of the Constitution . . . ." Id. at 394.

60. In Smith v. Maryland, 59 U.S. (18 How.) 71 (1855) the Court declared that the fourth amendment did not apply to the states. This holding was consistent with the then prevailing view that the protections of the Bill of Rights did not apply to the states. See Barron v. Mayor of Baltimore, 32 U.S. (7 Pet.) 243 (1833). However, the passage in 1868 of the fourteenth amendment with its due process requirement nullified this viewpoint.

61. 338 U.S. 25 (1949).

62. At the time of the Wolf decision the controversy over the parameters of the due process clause of the fourteenth amendment in relation to the rights granted under the first eight amendments had reached a point where Palko v. Connecticut, 302 U.S. 319 (1937), and Adamson v. California, 332 U.S. 46 (1947), cases holdmg that the fifth amendment self-incrimination protections did not apply to the states, were the majority view. In Palko the Court imdicated that only those rights "found to be imiphicit in the concept of ordered liberty" were absorbed by the due process clause. 302 U.S. at 325. Palko also relied upon language from Snyder v. Massachusetts, 291 U.S. 97 (1934), which addressed a "principle of justice so rooted in the traditions and conscience of our people as to be ranked as fundamental." Id. Four justices were of a contrary view. See Fairman, Does the Fourteenth Amendment Incorporate the Bill of Rights? The Original Understanding, 2 STAN. L. REv. 5 (1949). This "incorporation" controversy addressed in Wolf carried on long afterward. See, e.g., Duncan v. Louisiana, 391 U.S. 145 (1968). See generally Henkin, 'Selective Incorporation' in the Fourteenth Amendment, 73 YALE L.J. 74 (1963).

63. Jnstice Frankfurter stated that the "security of one's privacy against arbitrary intrusion by the police-which is at the core of the Fourth Amendment-is basic to a free society. It is therefore implicit in the 'concept of ordered liberty' and as such enforceable against the States through the Due Process Clause." Wolf v. Colorado, 338 U.S. at 27-28.

64. Id. at 28-29.

65. Id. at 30-33. The Court indicated that in state cases, unlike federal cases, the effectiveness of local public opimion could be significant. Id. at 32-33. 
implication."66 Dissenting, Justice Murphy argued that the only effective sanction for unlawful police conduct was the exclusionary rule. ${ }^{67}$

For five years after Wolf, the Court was asked repeatedly to overrule the case, but it expressly indicated that it would not consider doing so until the states had an "adequate opportunity to adopt or reject the [Weeks] rule."68 Finally recognizing the erosion of the doctrinal underpinnings of Wolf, ${ }^{69}$ the Court admitted in Mapp v. Ohio ${ }^{70}$ that the "other reinedies have been worthless and futile." 71 The Court concluded that miposition of the exclusionary rule on the states was necessary both to guarantee against "official lawlessness in flagrant abuse of that basic right"72 of privacy and to preserve the "judicial integrity so necessary in the true administration of justice." 73

With the Mapp decision the exclusionary rule reached its zenith. In its subsequent decisions the Court has refused to extend the reach of the exclusionary sanction to grand jury hearings ${ }^{74}$ and to civil federal tax cases. ${ }^{75}$ Moreover, it has refused to allow lower federal courts the option to entertain habeas corpus petitions challenging state court refusals to apply the sanction. ${ }^{76}$

The Court has not been consistent in justifying the exclusionary rule. As the Court's willingness to apply the exclusionary rule has dwindled, the substance of the rule's justification has varied. The imtial justification for the exclusionary rule was a constitutional one-the fourth amendment required the sanction. ${ }^{77}$ This theory of the exclusionary rule as a personal constitutional right was mixed later with the

66. Id. at $28-29$.

67. Justice Murphy observed that "there is but one alternative to the rule of exclusion. That is no sanction at all." Id. at 41 .

68. Irvine v. California, 347 U.S. 128, 134 (1954).

69. In Rea v. Uunted States, 350 U.S. 214 (1956), the Court upheld an injunction barring a federal officer, who had illegally seized evidence, from testifying in a state proceeding. A similar injunction, however, was refused in Wilson v. Schnettler, 365 U.S. 381 (1961). One coininentator criticized the Court's attempts to distinguisl these two cases as an exercise in hairsplitting. See Broeder, The Decline and Fall of Wolf v. Colorado, 41 NeB. L. REv. 185, 193 (1961). See also Elkins v. United States, 364 U.S. 206 (1960), which overruled the "silver platter" doctrine of Lustig v. United States, 338 U.S. 74 (1949).

70. 367 U.S. 643 (1961).

71. Id. at 652 .

72. Id. at 655 .

73. Id. at 660 . The Court recognized that one result of an exclusionary rule may be that the "criminal is to go free because the constable has blundered." Id. at 659 (quoting People v. Defore, 242 N.Y. 13, 21, 150 N.E. 585,587 (1926)).

74. United States v. Calandra, 414 U.S. 338 (1974). See text accompanying notcs 155-59 infra.

75. United States v. Janis, 428 U.S. 433 (1976). See text accompanying notes 160-64 infra.

76. Stone v. Powell, 428 U.S. 465 (1976). See text accompanying notes 165-69 infra.

77. See text accompanying notes 80-107 infra. 
theory that the rule was necessary to protect the integrity of the courts. ${ }^{78}$ Finally, these two theories were overshadowed by the flexible policy justification that the exclusionary rule deters police violations of the fourth amendment.79 An examination of the evolution of these three justifications for the exclusionary rule provides clues concerning the Court's willingness to apply the rule in OSHA proceedings.

\section{A. Personal Constitutional Right.}

The rationale for the exclusionary rule which inay have the most historical support, but unquestionably lias the least support on the present Court, is that the exclusionary rule is an integral part of the fourth amendment and thus is a personal right of constitutional dimensions. This thesis is, in fact, the original justification for the sanction.

In Boyd $v$. United States, ${ }^{80}$ the case that is the recognized precursor of the exclusionary rule, the Court creatively intertwined the fourth and fifth ainendments and held that evidence unreasonably seized in violation of the fourth amendment was a form of coinpelled self-incrimination that violated the fifth amendment. ${ }^{81}$ The Boyd rationale, although theoretically interesting, is tied inextricably to the particular facts of the case. Consequently, in Weeks v. United States ${ }^{82}$ Justice Day's inajority opinion was unable to rely on such creativity, and instead focused on the necessity of the exclusionary rule to the realization of fourth amendment rights. ${ }^{83}$ He stated simply that a failure to exclude evidence seized in violation of the fourth amendment was a "demial of the constitutional rights of the accused." 84

This early thesis that the fourth amendment itself prohibited the use of illegally obtamed evidence in judicial proceedings received support in cases decided during the 35 years following Weeks. ${ }^{85}$ In Gouled v. United States ${ }^{86}$ the Court held that tainted evidence had to be excluded in order to insure the "full enjoyment of personal liberty and private property." "87 The Court's rationale was that fourth amend-

\footnotetext{
78. See text accompanying notes 108-34 infra.

79. See text accompanying notes 135-69 infra.

80. 116 U.S. $616(1886)$.

81. Id. at $634-35$.

82. 232 U.S. 383 (1914).

83. See note 58 supra.

84. 232 U.S. at 398.

85. This constitutional justification finds strong support in several commentaries. See, e.g., Barreth, Exclusion of Evidence Obtained by Illegal Searches-A Comment on People v. Cahan, 43 CALIF. L. REv. 565 (1955); Cann \& Egbert, The Exclusionary Rule: Its Necessity in Constitutional Democracy, 23 How. L.J. 299 (1980).

86. 255 U.S. 298 (1921).

87. Id. at 304.
} 
ment protection of these rights was meaningless if the protection did not include an exclusionary sanction. In Byars $v$. United States ${ }^{88}$ a unanimous Court held that, under our constitutional system, a doctrine cannot be tolerated that allows evidence "of crime discovered by a federal officer in making a search without lawful warrant [to] be used agamst the victim of the unlawful search where a timely challenge has been interposed." 89 The constitutional dimensions of the exclusionary rule were clearly reiterated in Olmstead $v$. United States, ${ }^{90} \mathrm{~m}$ which the Court stated that the outcome of Weeks recognized that the fourth amendment forbids the introduction of illegally seized evidence. ${ }^{91}$

This rationale, that the fourth amendment mandates the exclusionary sanction, went undisturbed until Wolf $v$. Colorado, ${ }^{92}$ where the Court rejected the application of the exclusionary rule to the states. In Wolf the Court reversed its position, stating that the exclusionary rule "was not derived from the exphicit requirements of the Fourth Amendment."93 The Court recognized that the fourth amendment applies to the states, but it refused to require the states to use the exclusionary rule as the ouly sanction that would satisfy the minimum standards of the due process clause of the fourteenth amendment. ${ }^{94}$ The Court allowed the states to rely "upon other methods which, if consistently enforced, would be equally effective"9s in deterring unreasonable searches. ${ }^{96}$

Jettisoning the constitutional rationales of the exclusionary rule set it adrift on a sea of policy considerations. Thus freed from the Constitution, the Court was able to balance the costs of forcing the rule on the states against the probability of deterring illicit police conduct.

88. 273 U.S. 28 (1927).

89. Id. at 29-30. The Court stated further that the admission of illegally seized evidence "disregard[s] the plain spirit and purpose of the constitutional prohibitions intended to secure the people against unauthorized official action." Id. at 33.

90. 277 U.S. 438 (1928). This case evoked dissents by Justices Holmes and Brandeis that lend great support to the judicial integrity justification.

91. Id. at 462. Accord, Johnson v. United States, 333 U.S. 10 (1948); Go-Bart Importing Co. v. United States, 282 U.S. 344 (1931); cf. McNabb v. United States, 318 U.S. 332 (1943) (exclusion of evidence obtained in violation of federal statute).

92. 338 U.S. 25 (1949).

93. Id. at 28.

94. Id. at 31 .

95. Id.

96. The Court agreed:

[I]n practice the exclusion of evidence may be an effective way of detcrring unreasonable searches . . . [but we] cannot brush aside the experience of States which deem the incidence of such conduct by the police too slight to call for a deterrent remedy not by way of disciplinary ineasures but by overriding the relevant rules of evidence.

Id. at 31-32 (emphasis added). 
In Mapp v. Ohio ${ }^{97}$ the Court returned to the constitutional justification for the exclusionary rule in order to justify its reversal of $W o l f .98$ The Mapp Court reaffirmed the constitutional origin of the exclusionary rule as "an essential part of the right to privacy." 99 But the Court simultaneously signaled the imminent rejection of this thesis by referring to the deterrence rationale in the same analysis; ${ }^{100}$ any mention of the deterrence policy was unnecessary if the exclusionary rule had an independent constitutional foundation. ${ }^{101}$

Nevertheless Mapp appeared to settle any question concerning the constitutional basis of the exclusionary rule. But five years later, in Linkletter v. Walker, ${ }^{102}$ the Court avoided retroactive application of Mapp by denying the constitutional birthriglt of the exclusionary rule and instead focusing on deterrence. This radical departure from Mapp drew a sharp rebuke from Justice Black, who asked in his dissent, "What valid reason can justify keeping people in jail under convictions obtamed by wanton disregard of a constitutional protection which the Court itself in Mapp treated as being one of the 'constitutional rights of the accused?" "103

The Linkletter Court was faced with a difficult policy choice, which may explaim its failure to offer any justification for turning its back on the "personal constitutional right" theory. Unfortunately, this manipulation of the theory was repeated in United States v. Calandra. ${ }^{104}$ Philosophically displeased with the exclusionary rule, ${ }^{105}$ and notwithstanding Justice Brennan's protestations, ${ }^{106}$ the Court continued to adhere to the Wolf analysis of the rule's justifications. ${ }^{107}$

97. 367 U.S. 643 (1961).

98. The Court distinguished the Wolf decision as being fact specific. Id. at 650-51.

99. Id. at 656. The Court further stated: "[O]ur holding that the exclusionary rule is an essential part of both the Fourth and Fourteenth Amendinents is not only the logical dictate of prior cases, but it also nakes very good sense." Id. at 657 .

100. See note 147 infra.

101. See notes $80-91$ supra and accompanying text.

102. 381 U.S. 618 (1965).

103. Id. at 650 (Black, J., dissenting).

104. 414 U.S. 338 (1974). "In sum, the [exclusionary] rule is a judicially created remedy designed to safeguard Fourth Amendment rights generally through its deterrent effect, rather than a personal constitutional right of the party aggrieved." Id. at 348 .

105. See Burkoff, The Court that Devoured the Fourth Amendment: The Triumph of an Inconsistent Exclusionary Doctrine, 58 OR. L. Rev. 151 (1979).

106. In Calandra Justice Brennan, drawing on Mapp for support, concluded "there is no evidence that the possible deterrent effect of the rule was given any attention by the judges chiefly responsible for its formulation." 414 U.S. at 361.

107. See, e.g., Stone v. Powell, 428 U.S. 465 (1976); United States v. Janis, 428 U.S. 433 (1976); United States v. Peltier, 422 U.S. 531 (1975). See notes 127-31 infra and accompanying text. 


\section{B. Judicial Integrity.}

The rationale of judicial integrity encoinpasses two distinct but interrelated theories. First, the courts seek to protect their integrity by refusing to allow introduction of illegally seized evidence, thereby preventing the wrongdoer froin profiting froin his wrongdoing. Second, the courts' exclusion of illegally seized evidence safeguards the popular trust in governmental institutions that judicial countenance of fourth anendment violations would endanger. Both theories focus on the role of the court, first as a paradigm of rectitude and second as a role inodel instilling trust in government.

Whether or not one considers judicial integrity to be a valid rationale for an exclusionary rule nay depend ultimately on whether one views the role of a court from a "fragmentary" or "umitary" standpoint. ${ }^{108}$ In a "fragmentary" model, the court is seen as a separate entity froun the government as prosecutor. The judge's sole purpose is to insure a fair trial; he acts as a inere conduit for all evidence relevant to the fact-finding process. Thus, the court is not implicated, either retroactively or prospectively, in the illegal conduct that produced the evidence. ${ }^{109}$.The "fragmentary" inodel inay describe accurately litigation between private parties, but when the Government acts as prosecutor the effect of a court's ruling on future government conduct is too direct to support the inodel.

In contrast, the "unitary" inodel views the court as an integral part of an ongoing governmental process of which the prosecution is only one part. By refusing to exclude illegal evidence, the court engages in a continuing wrong. ${ }^{110} \mathrm{Judicial}$ integrity is imperiled both by condoning a past wrong and tacitly approving future wrongs. ${ }^{111}$ Thus, under a "unitary" model approach, the court seeks to foster respect for the gov-

108. For an excellent analysis of these concepts, see Schrock \& Welsh, Up From Calandra : The Exclusionary Rule as a Constitutional Requirement, 59 MiNN. L. Rev. 251 (1974).

109. See Wigmore, Using Evidence Obtained by Illegal Search and Selzure, 8 A.B.A.J. 479 (1922), in which, applying the common law rule that the admissibility of evidence is unaffected by the ineans used by the proponent to procure it, Wigmore considered the court morally neutral on the illegal conduct, not condoning it but merely ignoring it.

110. See Amsterdam, Perspective on the Fourth Amendment, 58 MinN. L. REv. 349, 432 (1974), which states that the court's acceptance of illegally obtained evidence is not morally neutral because the court is not merely ignoring or tolerating wrongful conduct, but is inducing future illegal searches and seizures by sending forth a message that such searches still will reap benefits in a criminal trial.

111. As one commentator eloquently summarized: "[T]he government is an mdivisible entity, the prosecution is a single process, and there is no honest way to give the court a moral release for wrongful conduct on the part of the executive in a prosecution inade possible only by the participation of both the court and the executive." Schrock \& Welsh, supra note 108, at 262. 
ernment, of which it is an integral part, and to avoid besmirching its own integrity by entangling itself in lawless conduct.

Discussion of judicial integrity predates discussion of deterrence in exclusionary rule case law. ${ }^{112}$ Indeed, in Weeks itself, there is language which lends credence to the statement that among the original purposes of the exclusionary rule was the preclusion of judicial participation in illegal government conduct. ${ }^{113}$

What was in Weeks a subtle admomition for courts to protect themselves from the taint of illegal government conduct became an overt challenge im the dissenting opinions of Justices Holmes and Brandeis in Olmstead $v$. United States. ${ }^{114}$ With renarkable insight, Justice Holmes stated every justification for the exclusionary rule that forms the basis of the "unitary" model. He expressed concern that allowing the imtroduction of illegally obtained evidence was tantainount to judicial encouragement of future violations by signaling the court's imtent to make such violations worthwhile. ${ }^{115}$

Justice Brandeis was similarly concerned about the role the court plays when it allows a prosecution to continue after the Government, in seeking to admit evidence, "[is] obliged to lay bare the crimes committed by its officers on its behalf." 116 Justice Brandeis analyzed the ongoing "wrong" in three stages: the enforcement officer, the prosecutor, and the judge each in turn commits or ratifies the breach of the fourth amendment."17 Thus, "the Government itself [becomes] a lawbreaker," 118 encouraging future wrongdoing and presenting an in1proper example of lawlessness for the governed. ${ }^{119}$ As recently as the

112. Compare Weeks v. United States, 232 U.S. 383 (1914) with Wolf v. Colorado, 338 U.S. 25 (1949).

113. "[T]o obtain convictions by means of unlawful seizures . . . should find no sanction in the judgments of the courts which are charged at all times with the support of the Constitution." Weeks v. United States, 232 U.S. at 392 (emphasis added).

114. 277 U.S. 438 (1928). Chief Justice Taft, writing for the Court, refused to extend the exclusionary rule to a wiretap situation which the majority did not consider to be violative of the Fourth Amendment because only state officials were involved.

115. Justice Holmes remarked:

If [the government] pays its officers for having got evidence [sic] by crime I do not see why it niay not as well pay them for getting it in the same way, and I can attach no importance to protestations of disapproval if it knowingly accepts and pays and announces that in the future it will pay for the fruits.

Id. at 470 (Holmes, J., dissenting).

116. Id. at 480 (Brandeis, J., dissenting).

117. Id. at 483 .

118. Id

119. Id at 485. For additional treatment of the "faith in governmental institutions" analysis, see Paulsen, The Exclusionary Rule and Misconduct by the Police, 52 J. CRIM. L.C. \& P.S. 255, 258 (1961). 
decisions in Elkins $v$. United States ${ }^{120}$ and Mapp $v$. Ohio, ${ }^{121}$ the concept of judicial imtegrity still received deferential treatment. With the advent of the retroactivity problem in Linkletter $v$. Walker, ${ }^{122}$ however, the judicial integrity thesis suffered. The Court was unable to defend convincingly its unwillingness to make Mapp retroactive under a judicial integrity theory. Therefore judicial integrity had to take a secondary position to deterrence in order for the Court to piece together an internally consistent decision. ${ }^{123}$

Judicial integrity language appears sporadically in the Court's decisions since Mapp. The rationale was revived briefly in Terry $v$. Ohio, ${ }^{124}$ only to be interred in United States $v$. Calandra, ${ }^{125}$ in which the Court made deterrence its preeminent justification. The Calandra Court paid only ritualistic deference to judicial integrity; the principal proponent of this rationale, Justice Brennan, thus became a lone voice in dissent. He lamented that the Court had discounted judicial integrity to "the point of extmction." 126

In United States $v$. Peltier, ${ }^{127}$ another retroactivity case, ${ }^{128}$ the Court stressed that the judicial integrity argument was not dead, but was of secondary importance. Of primary concern was the deterrence rationale. ${ }^{129}$ Rather than give judicial integrity summary treatment, as the Calandra Court did, the Peltier Court instead attempted to justify

120. 364 U.S. 206 (1960). The Elkins Court noted that courts should not become "accomplices in the willful disobedience of a constitution they are sworn to uphold." Id. at 223.

121. 367 U.S. 643 (1961). The Mapp Court, in addressing the "imperative of judicial integrity," stated that: "Nothing can destroy a government more quickly than its failure to observe its own laws, or worse, its disregard of the charter of its own existence." Id. at 659.

122. 381 U.S. 618 (1965).

123. The result was that while the Linkletter court gave polite mention to judicial integrity, the court relegated it to a drastically inferior role. Id. at 637 .

124. 392 U.S. 1 (1968). The Terry Court noted:

Courts which sit under our Constitution cannot and will not be made party to lawless invasions of the constitutional rights of citizens by permitting unhindered governmental use of the fruits of such invasions. . . A ruling admitting evidence in a criminal trial, we recognize, has the necessary effect of legitimizing the conduct which produced the evidence, while an application of the exclusionary rule withholds the constitutional imprimatur.

Id. at 13.

125. 414 U.S. 338 (1974).

126. Id. at 360 (Brennan, J., dissenting).

127. 422 U.S. 531 (1975).

128. Peltier involved retroactive application of Almeida-Sanchez v. United States, 413 U.S. 266 (1973), which held that a warrantless automobile search, conducted approximately 25 miles from the Mexican border by border patrol agents who acted without probable cause, violated the fourth amendment.

129. 422 U.S. at 536. The Court stated: "Decisions of this Court applying the exclusionary rule to unconstitutionally seized evidence have referred to the imperative of judicial integrity, Elkins v. United States, 364 U.S. 206, 222 (1960), although the Court has rehed principally upon the deterrent purpose served by the exclusionary rule." $I d$. 
its nonapplicability to retroactivity cases: if a law enforcement officer acts in good faith at the time of the seizure, a subsequent change in the law does "not make the courts 'accomplices in the willful disobedience of a Constitution they are sworn to uphold." "130 Thus, at least in the retroactivity area, the Court was willing to state that the judicial integrity analysis did not differ markedly in result from the deterrence rationale, as neither provided a justification for extending the exclusionary sanction retroactively. ${ }^{131}$

To the dismay of judicial imtegrity supporters, the decision in United States $v$. Janis ${ }^{132}$ extinguished the faint hope held out in Peltier that judicial integrity would continue to be a legitimate consideration. The Janis Court took cursory notice of judicial integrity133 and reemphasized the Calandra language that deterrence is the prime purpose of the exclusionary rule. ${ }^{134}$ After Janis any prediction of the future of the exclusionary rule must rely on an analysis of this youngest and most flexible justification for the exclusionary rule-deterrence of police misconduct.

\section{Deterrence of Official Misconduct.}

A inajority of the justices has agreed that the primary, if not the sole, purpose of the exclusionary rule is to deter unlawful police conduct. ${ }^{135}$ This bold pronouncement has been criticized as being of re-

130. Id. (quoting Elkins v. United States, 364 U.S. 206, 223 (1960)). The Court also stated: The teaching of these retroactivity cases is that if the law enforcement officers reasonably believed in good faith that evidence they had seized was admissible at trial, the "imperative of judicial integrity" is not offended by the introduction into evidence of that material even if decisions subsequent to the search or seizure liave broadened the exclusionary rule to encompass evidence seized in that manner.

Id. at 537.

131. Id. at 538-39, 542. See also Michigan v. Tucker, 417 U.S. 433, 447 (1947).

132. 428 U.S. 433 (1976). Janis involved evidence illegally seized by state criminal investigators who turned it over to federal officers for use in a civil tax action.

133. The Court noted:

The primary meaning of "judicial integrity" in the context of evidentiary rules is that the courts must not commit or encourage violations of the Constitution. In the Fourth Amendment area, however, the evidence is unquestionably accurate, and the violation is complete by the time the evidence is presented to the court. . . . The focus therefore must be on the question whether the admission of the evidence encourages violations of Fourth Amendment rights. As the Court has noted in recent cases, this imquiry is essentially the same as the inquiry into whether exclusion would serve a deterrent purpose.

Id. at 458-59 n.35 (citations omitted). The Court, by the convenient device of redefining "judicial integrity" to suit its purpose, thus can summarily dispose of the concept of "judicial integrity" without dealing with its broader connotations, such as condoning an illegal act by allowing its utilization in a court of justice. The Court thus assumes that a trial court is a passive recipient whose acceptance does not carry an imprimatur. This premise is unsupportable.

134. $I d$.

135. See id. at 446. 
cent origin. ${ }^{136}$ Deterrence was not mentioned im connection with the exclusionary rule until the Court decided Wolf $v$. Colorado ${ }^{137}$ thirtyfive years after the rule's adoption in Weeks v. United States. ${ }^{138}$

In Elkins v. United States ${ }^{139}$ the Court focused on the deterrent purpose of the exclusionary rule im order to reject the "silver platter" doctrine. ${ }^{140}$ That doctrine allows federal officials to introduce in federal trials evidence that has been obtained unlawfully by state offcials. ${ }^{141}$ The Court sought to deter unlawful police conduct by removing any incentive for police to engage in such activity. ${ }^{142}$

Though the Court did not consider deterrence to be the sole justification, ${ }^{143}$ even the dissent agreed that it was a compelling one. ${ }^{144}$ The rationale of the Elkins Court reappeared in Mapp v. Ohio, ${ }^{145}$ which overruled $W o l f$ by extending the exclusionary rule to state criminal proceedings. ${ }^{146}$ The Court used deterrence language, albeit more subtly than in Elkins, to justify the existence of an exclusionary rule. ${ }^{147}$

In Linkletter v. Walker ${ }^{148}$ the Court, in determining the prospective or retroactive application of Mapp, obviously was concerned with the repercussions of making Mapp retroactive. To avoid overburdening the administration of justice by allowing innumerable final state convictions to be reopened on Mapp grounds, the Court inade a policy decision for which the deterrence arguinent could lend the greatest support. ${ }^{149}$ The Court stated that it had to look, inter alia, to the "pur-

136. See, e.g., Cann \& Egbert, supra note 85 .

137. 338 U.S. 25 (1949).

138. 232 U.S. 383 (1914); see, e.g., Cann \& Egbert, supro note 85.

139. 364 U.S. 206 (1960).

140. Id. at 217-21.

141. Lustig v. United States, 338 U.S. 74, 78-79 (1949). See generally Ringel, SEARCHES AND SEIZURES, ARRESTS AND CONFESSIONS $\$ 4$ (1972).

142. 364 U.S. at 217. The Court stated: "The rule is calculated to prevent, not to repair. Its purpose is to deter-to compel respect for the constitutional guaranty in the only effectively available way-by removing the incentive to disregard it." Id.

143. See id. at 215-16 (referring to concepts of judicial integrity).

144. In his dissenting opinion, Justice Frankfurter noted that "the exertion of controlling pressures upon the police is admittedly the only justification for any exclusionary rule." Id. at 241 (Frankfurter, J., dissenting).

145. See 367 U.S. 643,656 (1961).

146. Id. at 655 .

147. The opinion reads in part:

This Court has ever since [Weeks] required of federal law officers a strict adherence to that command which this Court lias held to be clear, specific, and constitutionally required-even if judicially implied - deterrent safeguard without insistence upon which the Fourth Amendment wonld have been reduced to "a form of words."

Id. at 648 (emphasis added).

148. 381 U.S. 618 (1965).

149. In all fairness to the Court, retroactivity decisions have been among the toughest to resolve to the complete accommodation of the conflicting viewpoints. On the one hand the Court 
pose" served by the exclusionary rule; the purpose it found was the deterrence rationale. ${ }^{150}$ The Court discarded the constitutional right and the judicial integrity theories. ${ }^{151}$ Whether or not this purpose was consistent with the history of the exclusionary rule, ${ }^{152}$ the preeminence of the deterrence rationale was unmistakable. The Court has continued to tout deterrence as the dominant purpose of the exclusionary rule; ${ }^{153}$ the personal constitutional right theory has not reappeared; and the judicial integrity theory, despite its brief comeback, ultimately paled into insignificance. ${ }^{154}$ In United States $v$. Calandra ${ }^{155}$ the Court stated that "the rule's prime purpose is to deter future unlawful police conduct . . .".156

Thus it becaine clear that the exclusionary rule was going to live or die on the basis of its utility as a deterrent device. By factoring out the justifications which keep their force regardless of the factual context of the case, the Court deinoted the question of the exclusionary rule's applicability to one of judicial policy only; the Court was free to balance the beneficial deterrent effects of extending the rule against the harm to the institution involved.

In Calandra the Court refused to extend the exclusionary rule to grand jury proceedings. ${ }^{157}$ The Court concluded that "any incremental deterrent effect which might be achieved by extending the [exclusionary] rule to grand jury proceedings is uncertain at best," 158 but that the harm to the institution of the grand jury is certain and ultimately "out-

announces that prior law was wrong, but, on the other, realistically does not want to upset the administration of justice by compelling relitigation of all cases no matter how far in the past they may have occurred. Indicative of the difficulty of retroactivity issues are Desist v. United States, 394 U.S. 244 (1969) (retroactivity of Katz v. United States, 389 U.S. 347 (1967)) and Fuller v. Alaska, 393 U.S. 80 (1968) (retroactivity of Katz v. United States, 389 U.S. 347 (1967)).

150. 381 U.S. at 636-37.

151. See notes 80-134 supra and accompanying text.

152. This issue did not escape the attention of Justice Black in his dissent where he noted:

I have read and reread the Mapp opinion but have been unable to find one word in it to indicate that the exclusionary search and seizure rule should be limited on the basis that it was intended to do nothing in the world except to deter officers of the law.

Linkletter v. Walker, 381 U.S. at 649 (Black, J., dissenting).

153. In Terry v. Ohio, 392 U.S. 1,12 (1968), the Court noted that the "inajor thrust [of the exclusionary rule] is a deterrent one." Also, in his dissent in Bivens v. Six Unknown Named Agents, 403 US. 388 (1971), Chief Justice Burger, while unleashing a frontal assault on the need for an exclusionary rule, contended that deterrence was the raison d'etre of the rule.

154. See notes 80-134 supra and accompanying text.

155. 414 U.S. 338 (1974).

156. Id. at $347-48$ (footnote omitted).

157. 414 U.S. 338 (1974). The Court specifically declined to consider the extent of the rule's practical efficacy in criminal trials. Id. at $348 \mathrm{n} .5$.

158. Id. at 351 . 
weighs the benefit of any possible incremental deterrent effect."159 Two years later in United States $v$. Janis ${ }^{160}$ the Court refused to extend the exclusionary sanction to a civil tax liability case solely on the basis of lack of sufficient deterrent effect. ${ }^{161}$ Given the attenuation in intersovereign situations "further augmented by the fact that the proceeding is one to enforce only the civil law of the other sovereign,"162 the Court concluded that the exclusionary rule is "unlikely to provide significant, inuch less substantial, additional deterrence" 163 to the criminal law enforcement officials of the offending sovereign. ${ }^{164}$

Fimally, in Stone v. Powell, ${ }^{165}$ a state prisoner sought federal habeas corpus relief from a state court conviction wherein the prosecution had relied upon evidence obtained by searches and seizures alleged by the defendants to have been in violation of his fourtl aunendment rights. The Court, postulating that federal review of State fourth amendment decisions would provide de minimis deterrence, refused to allow federal courts to review such state decisions. ${ }^{166}$ Once again deterrence was the focal point of the attempt to justify the exclusionary rule, and judicial integrity was reduced to virtual irrelevance. ${ }^{167}$

In Stone and earlier cases imvolving the deterrence theory, the Court had been willing to accept the deterrence rationale despite an admitted lack of einpirical data supporting it. ${ }^{168}$ So long as the Court is

159. Id. at 354 .

160. 428 U.S. 433 (1976).

161. Id. at 457. The Court stated: "To the extent that the court did not focus on the detcrrent purpose of the exclusionary rule, the law has since been clarified."

162. Id. at 458.

163. Id. Also significant was that federal civil tax liability was "outside the offending officer's zone of primary interest." Id.

164. The opinion provides further evidence of the demise of "judicial integrity" as a convincing justification: "To the extent that recent cases state that deterrence is the prime purpose of the exclusionary rule, and that 'judicial integrity' is a relevant, albeit subordinate factor, we hold that in this case considerations of judicial integrity do not require exclusion of the evidence." Id. at 458 n. 35 .

165. 428 U.S. 465 (1976).

166. "In this context the contribution of the exclusionary rule, if any, to the effectuation of the Fourth Amendment is minimal and the substantial societal costs of application of the rule persist with special force." Id. at 494-95 (footnote omitted).

167. "While courts, of course, must ever be concerned with preserving the integrity of the judicial process, this concern has limited force as a justification for the exclusion of highly probative evidence." Id. at 485 (footnote omitted).

168. Of the many attempts to compile einpirical data, the most noteworthy is Oaks, Studying the Exclusionary Rule in Search and Seizure, 37 U. CH1. L. Rev. 665 (1970). Unfortunately the results of such attempts are imconclusive. See.also Andenas, The Morality of Deterrence, $37 \mathrm{U}$. CHI. L. Rev. 649 (1970); Kamisar, Does the Exclusionary Rule Affect Police Behavior?, 62 Jud. 70 (1978); Spiotto, Search and Seizure: An Empirical Study of the Exclusionary Rule and Its Alternatives, 2 J. LEGAL STUD. 243 (1973). 
willing to assume that the deterrence rationale is empirically sound, the exclusionary rule probably will not be rejected outright, at least in the absence of proven alternatives. ${ }^{169}$ The Court has used a "divide and conquer" approach, separating the right found in the fourth anendment from the remedy, the exclusionary rule. This isolation of the evidentiary use of the violation's product from the violation itself is historically indefensible. Be that as it nay, the realities of the present composition of the Supreme Court require that any attempt to extend the exclusionary rule into new areas must be justified on a deterrence basis.

\section{Present Status of the Law}

In Marshall v. Barlow's, Inc., ${ }^{170}$ the Supreme Court ruled that fourth amendment protections were applicable to OSHA compliance inspections. The case, however, dealt only with whether the requested declaratory and mjunctive relief should be granted; the Court was not required to decide the applicability of the exclusionary sanction to OSHA inspections. ${ }^{171}$ Prior to Barlow's, courts presuned the fourtli amendment was mapplicable to OSHA inspections, so they never fully addressed the issue of applying the exclusionary sanction to such imspections. ${ }^{172}$ Since the Barlow's decision resolved the fourth amendment applicability issue, the exclusionary sanction has not been definitively addressed by the OSHRC or any federal appellate court, but has been noted by the courts as a "sharply contested question"173 and "an unsettled and highly controversial area of the law."174 The two judicial decisions and two OSHRC decisions rendered after the

169. For example, Chief Justice Burger stated in his Bivens dissent: "I do not propose, however, that we abandon the suppression doctrine until some meaningful alternative can be developed." Bivens v. Six Unknown Named Agents, 403 U.S. 388, 420 (1971) (Burger, C.J., dissentimg). Then, in his Stone concurrence, the Chief Justice noted: "Incentives for developing new procedures or remedies will remain minimal or nonexistent so long as the exclusionary rule is retamed in its present form." 428 U.S. at 500 (Burger, C.J., concurring).

170. 436 U.S. 307 (1978).

171. The Supreme Court held that an einployer "was entitled to a declaratory judgment that the [OSHA] is unconstitutional insofar as it purports to authorize inspections without warrant or its equivalent and to an injunction enjoining the Act's enforceinent to that extent." Id. at 325 .

172. In Accu-Namics, Inc. v. OSHRC, 515 F.2d 828 (5th Cir. 1975), the court held that ininor violations by the compliance officer failed to establish any prejudice. The inspection had not violated any fourth amendment rights of the employer, and even if the inspection had been illegal, the exlusionary rule would not have been invoked absent a showing of prejudice to the employer. Id. at 833-34. Accord, Hoffman Constr. Co. v. OSHRC, 546 F.2d 281 (9th Cir. 1976).

173. Babcock and Wilcox Co. v. Marshall, 610 F.2d 1128, 1139 (2d Cir. 1979). The court observed that OSHRC might apply the exclusionary rule as a matter of policy, regardless of any federal court determination of applicability. Id

174. Cerro Metal Prods. v. Marshall, 620 F.2d 964, 974 (3d Cir. 1980). 
Barlow's decision that deal at length with the exclusionary rule held that because Barlow's was not retroactive, the direct applicability, and hence the exclusionary rule, questions need not be decided.

In Todd Shipyards Corp. v. Secretary of Labor, ${ }^{175}$ decided several months after Barlow's, the Court of Appeals for the Nintlı Circuit noted that neither the Supreme Court nor that court had ever applied the exclusionary rule to OSHA searclies. ${ }^{176}$ Indeed, the court stated in passing that because "the Supreme Court has never applied the exclusionary rule in a civil proceeding . . . the rule should not be applied to OSHA proceedings." 177 The court found it unnecessary to base its opinion on a civil/criminal dichotomy because under general retroactivity case law concerning the criminal exclusionary sanction, Todd would still not prevail. ${ }^{178}$ Drawing support from Almeida-Sanchez $v$. United States, ${ }^{179}$ the court concluded that the exclusionary rule does not affect the integrity of the fact-finding process and thus should not receive retroactive application even if prospective application were conceded arguendo. The "deterrent" effect would not be enhanced by applying the rule to searches oceurring before the constitutional limits were announced in Barlow's. ${ }^{180}$ Furthermore, because the compliance officers relied in good faith on the then-prevailing constitutional norms, such a denial of retroactivity did not "contravene the imperative of judicial imtegrity." "181 Based on the lolding of Stone v. Powell ${ }^{182}$ that the exclusionary rule "is a judicially created remedy designed to safeguard fourth amendment rights of the society as a whole through its deterrent effect on future unlawful police conduct," 183 the Todd court rejected the contention that the exclusionary rule was a "personal right." The court left for another day the question of whether it would apply the exclusionary rule to an OSHA search in a proper case. ${ }^{184}$

Contrary dictum appears in Savina Home Industries v. Secretary of

175. 586 F.2d 683 (9th Cir. 1978).

176. Id. at 689. The Supreme Court remanded some cases in light of Barlow's, but none of these cases involved the application of the exclusionary rule. See, e.g., United States v. Consolidated Coal Co., 579 F.2d 1011 (6th Cir. 1978); United Statcs v. Mississippi Power \& Light Co., 577 F.2d 1030 (5th Cir. 1978).

177. 586 F.2d at 689.

178. The court cited Linkletter v. Walker, 381 U.S. 618, 636-37 (1965) and United States v. Peltier, 422 U.S. 531 (1975), as support for this position.

179. 413 U.S. 266 (1973). See note 128 supra.

180. 586 F.2d at 690 .

181. Id.

182. 428 U.S. 465 (1976).

183. 586 F.2d at 690 .

184. Id. at 691. The Court of Appeals for the Ninth Circuit reaffirmed the prospective application of Barlow's in Usery v. Lacy, 628 F.2d 1226 (9th Cir. 1980). 
Labor, ${ }^{185}$ the only other judicial decision to address OSHA and the exclusionary rule. Although the decision of nonretroactivity was consistent with Todd, the Savina court considered the potential applicability of the exclusionary rule to OSHA inspections:

Even if the warrant protections of Barlow's are retroactively applicable to pre-Barlow's OSHA inspections, a conclusion that the inspection in this case violated the Fourth Amendment would be of no practical significance in the absence of an exclusionary sanction. If the exclusionary rule were inapplicable, even if a constitutional violation were to be found, no reinedy would be available in this case. ${ }^{186}$

The court also discussed the appropriateness of the exclusionary rule in light of the nature of the proceedings and the utilitarian value of the sanction.

Unlike the Todd court, which disposed of the nature of the proceedings with a passing reference to United States $v$. Janis, ${ }^{187}$ the Savina court was not convinced that Janis precluded application of an exclusionary rule in noncriminal proceedings. The peculiar facts of Janis resulted in a finding that the deterrence value of the sanction is not enhanced in an intersovereign criminal/civil case, not that the sanction is inapplicable solely on the basis of the civil nature of the proceedings. ${ }^{188}$ Additionally, in contrast to Janis, the Savina court noted that the Supreme Court had "approved application of the exclusionary rule in certain civil cases characterized by it as 'quasi-criminal," "I89 and further that several appellate courts had apphed the rule to civil and administrative cases. 190 The court inentioned, without deciding, that OSHA proceedings are arguably "quasi-criminal."191 However, the real basis for the Savina court's conclusion that the sanction applied rested on the purposes that the rule serves. The court stated that "considerations of preserving judicial integrity and deterring official lawlessness do not become inconsequential simply because an illegal search is conducted by the Department of Labor instead of by

185. 594 F.2d 1358 (10th Cir. 1979).

186. Id. at 1361 (footnote omitted).

187. 428 U.S. 433 (1976). See notes 160-64 supra and accompanying text.

188. Id. at 1362. Indeed, the Savina court actually concluded that "the analysis in Janis indicates that the deterrence rationale would have significance in an 'intrasovereign' case like the one before us." Id. n.5.

189. Id. at 1362.

190. Id. The Court rendered a short synopsis of some of these cases, including Midwest Growers Coop. Corp. v. Kirkemo, 533 F.2d 455 (9th Cir. 1976); Pizzarello v. United States, 408 F.2d 579 (2d Cir.), cert. denied, 396 U.S. 986 (1969); Knoll Assoc. v. FTC, 397 F.2d 530 (7th Cir. 1968).

191. 594 F.2d at 1362 n.6. 
the Department of Justice." 192 After concluding that the exclusionary rule would be applicable, the Savina court rejected its application in the instant case on the basis of the exclusionary rule retroactivity analysis ${ }^{193}$ found in United States $v$. Peltier. ${ }^{194}$ When this sanction is involved, the focus of the retroactivity analysis is "whether the purposes underlying the exclusionary rule would be furthered by retroactive application."195 Because the compliance officer had neither actual nor constructive knowledge of the unconstitutionality of warrantless OSHA inspections, the court concluded that the purposes of the exclusionary rule would not be served by its retroactive application. ${ }^{196}$

The decisions of the OSHRC are consistent with the judicial decisions in that Barlow's was not applied retroactively and the applicability of the exclusionary rule is unresolved. In Meadows Industries, Inc. ${ }^{197}$ the OSHRC agreed with the Todd and Savina courts that because the inspection occurred prior to Barlow's, the issue before the commission was retroactivity and not the applicability of the exclusionary rule itself. ${ }^{198}$ While concurring in the retroactivity analysis, the OSHRC did not state any opinion regarding the Todd-Savina split over potential application of the sanction in a proper case. The OSHRC analysis, however, did refer to the Janis language that "deterrence" is the "prime purpose" of the rule, if not the "sole one."199 This reference may signal the OSHRC's intention to rely heavily on the deterrence purpose, relegating the judicial integrity and personal constitutional

192. Id. at 1363 (footnote omitted). Although the court cited Mapp v. Ohio, it did not base its statement on the additional purpose set forth in Mapp that the rule is a personal constitutional right. The court probably elected not to do so based on subsequent language in Calandra, Janis and Peltier. The court, however, still forcefully relied on the judicial integrity rationale despite the diminished role judicial integrity lias been given in cases after Mapp. See notes 124-34 supra and accompanying text.

193. Unlike conventional retroactivity analysis, the Peltier approach does not emphasize whether there is a "new" rule that is a "sharp break" from prior authorities. See, e.g., Chevron Oil Co. v. Huson, 404 U.S. 97, 106-07. (1971).

194. 422 U.S. 531 (1975).

195. 594 F.2d at 1363. This, of course, differs from the conventional test of Stovall v. Denno, 388 U.S. 293 (1967), which considers (1) the purpose to be served by the new standard; (2) the extent of reliance by law enforcement officers on the prior standard; and (3) the effect that a retroactive application would have on the administration of justice. Id. at 297.

196. 594 F.2d at 1364. Savina's accord with Todd on this point is not surprising because the Supreme Court seems predisposed to give only prospective application to fourth amendment cases. See Beytagh, Ten Years of Non-Retroactivity: A Critique and a Proposal, 61 VA. L. Rev. 1557 (1975).

197. 7 Occupational Safety \& Health Cas. 1709 (Review Comm'n Dec. 1979).

198. The review commission reversed the administrative law judge on a different ground, one dealing with section 9(a) provisions for the amount of particularity necessary in a complaint. Id. at 1710 .

199. Id. at 1712. 
right rationales to secondary roles. Conversely, this language may be indicative only of a failure to closely analyze the distinct purposes of the exclusionary rule.

Finally, in Daniel International Corp. ${ }^{200}$ the OSHRC was faced with a situation similar to that in Meadows. The Supreme Court issued the Barlow's decision during the pendency of the Daniel hearing before the administrative law judge, so the einployer in Daniel presented more specific objections at the hearing than did the employer in Meadows. In Daniel the einployer argued that section 8(a) was rendered "ineffective and void for all times" by Barlow's and thus ab initio the inspection was conducted without proper authorization; that Barlow's was not a "new rule" but only a reaffirmation of "well-established Fourth Amendment standards dating back to" Camara and See, and thus the issue was not retroactivity; that under general retroactivity principles Barlow's should be applied retroactively; and that even if only prospective application were given to Barlow's, such application should be granted to hearings held after Barlow's and not just inspections conducted after Barlow's. ${ }^{201}$

On the basis of Todd Shipyards Corp. v. Secretary of Labor, ${ }^{202}$ the administrative law judge denied retroactive application of Barlow's without deciding the applicability question. When the case was appealed to the OSHRC, the employer expanded his argument to assert "that apphication of the exclusionary rule is the proper reinedy in Coinmission proceedimgs for unconstitutional searches and seizures" because such proceedings fall into the "quasi-criminal" category. ${ }^{203}$ The Secretary of Labor responded that, on the basis of the Todd dicta, the exclusionary rule should not be applied in OSHRC proceedings; that the potential injury to OSHA enforceinent if the rule were applied would outweigh the potential deterrent effects against unlawful conduct by a coinpliance officer; and that on the basis of Todd and Savina, Barlow's should not be retroactively applied to inspections occurring

200. 8 Occupational Safety \& Health Cas. 1142 (Review Comm'n Dec. 1980).

201. Id. at 1145. The Daniel employer expanded upon these contentions at the OSHRC hearing:

Barlow's did not overrule past clear precedent. Instead, it affirmed a lower court decision which followed the greater weight of authority. The OSHA comphance officers, therefore, were, im 1977, properly charged with knowledge that section 8(a) nonconsensual searches were unconstitutional. Thus, the imperative of judicial integrity commands that Barlow's be applied and the evidence seized be excluded.

Id. at $1146 \mathrm{n} .9$.

202. See notes 175-84 supra and accompanying text.

203. 8 Occupational Safety \& Health Cas. at 1146. The employer cited One 1958 Plymouth Sedan v. Pennsylvania, 380 U.S. 693 (1965), in support of this reasoning. 
prior to the Barlow's decision. ${ }^{204}$

The OSHRC rejected all of the employer's arguments. It found section 8(a) not to be "void for all times" and found that any inspection, such as a proper consent search, that did not violate the fourth amendment was still valid. ${ }^{205}$ Further, the OSHRC declared that retroactivity was indeed the issue in the case. The OSHRC concluded that under the state of the law that existed at the time of the search, the compliance officers had no actual or constructive knowledge of the unconstitutionality of their warrantless inspections. ${ }^{206}$ Finally, the OSHRC decided that the "application of Barlow's to cases arising from pre-Barlow's inspections but brought to learing after Barlow's would not enhance the purposes of the exclusionary rule."207 Although the OSHRC lieard arguments touching upon two key determinants of the rule's applicability - the nature of the hearing and the potential for enhancement of the purposes of the rule-it elected not to decide the Daniel case on this question. Instead, the commission properly based the decision on retroactivity, like the decisions in Todd, Savina and Meadows. Thus, when the OSHRC eventually decides whether the exclusionary rule is a proper remedy for fourtl amendment violations in the OSHA context, it will do so without significant guidance from existimg cases. As Daniel demonstrates, however, the decision ultimately will turn on a coinparison of the nature of OSHA penalties and hearings to other noncriminal proceedings, and a determination whether applying the sanction in the OSHA context will further the purposes of the exclusionary rule.

\section{Nature of OSHRC Penalties and Hearings}

A superficial appraisal of the OSHA review process could lead to a premature conclusion that the proceedings are purely civil. The Department of Labor processes the case, not the Department of Justice; an administrative law judge lears the case, not a federal district court judge; initial appeal, which is discretionary, is to the OSHRC, an administrative tribunal, not to a "traditional" court, at least in the first instance; the Federal Rules of Civil Procedure govern the proceedmgs, ${ }^{208}$ not the Federal Rules of Criminal Procedure; and the Solicitor of Labor handles appeals to the Supreme Court, not the Solicitor Gen-

204. Id.

205. Id. at 1147.

206. Id. at $1147-48$.

207. Id. at 1148.

208. 29 U.S.C. $§ 661(f)$ (1976). The Federal Rules of Civil Procedure apply to the extent that the OSHRC has not adopted a different rule. 
eral. ${ }^{209}$ The possible penalties, however, include some that are criminal, ${ }^{210}$ some that are obviously civil, ${ }^{211}$ and some that, although categorized as "civil," are arguably "quasi-criminal."212 No bright-line formula exists to determine if these combimed factors make an OSHRC hearing "criminal," "quasi-criminal" or "civil-administrative." The distinction is critical because the nore a proceeding can be characterized as "criminal," the greater the justification is for extending the exclusionary rule to it. Conversely, the more "civil-administrative" the proceeding, the weaker the justification.

The nature of the OSHRC hearing is best determined by studying the civil monetary penalty. Calling the penalty "civil," however, is hardly conclusive as to its true character. The determination of when penalties are civil, criminal, or quasi-criminal has plagued the courts for at least a century. ${ }^{213}$ In Kennedy v. Mendoza-Martinez ${ }^{214}$ the Supreme Court addressed the problem of properly characterizing a penalty as "civil" or "criminal," concluding that forfeiture of citizenship $^{215}$ was penal rather than regulatory. The Court's analysis formalized the elements to be considered in making such a determination:

The punitive nature of the sanction here is evident under the tests traditionally applied to determine whether an Act of Congress is penal or regulatory in character, even though in other cases this problem has been extremely difficult and elusive of solution. Whether the sanction involves an affirmative disability or restraint, ${ }^{216}$ whether it has historically been regarded as a punish-

209. 29 U.S.C. $\S 663$ (1976).

210. The statute provides for imprisonment if: (1) a willful violation results in the death of an employee, 29 U.S.C. $\$ 666(\mathrm{e})$ (1976); (2) unauthorized advance notice of an inspection is given, id. $\$ 666(\mathrm{f})$; (3) false statements or representations are inade concerning, inter alia, records required to be maintained, id. $\S 666(\mathrm{~g})$; or (4) a person engaged in the enforcement of the Act is inurdered, 18 U.S.C. \& 1114 (Supp. III 1979). These provisions also provide for fines ranging froin $\$ 1000$ to $\$ 20,000$.

211. See 29 U.S.C. $\$ 658$ (1976) (providing for the issuance of abatement orders).

212. See 29 U.S.C. $\$ 666$ (a)-(d), (h) (providing for both mandatory and permissive civil penalties up to $\$ 10,000)$.

213. In Boyd v. United States, 116 U.S. 616 (1886), the Court justified its application of fourth and fifth amendinent principles to the forfeiture action by classifying the penalty as "quasi-criminal." Id. at 634.

214. 372 U.S. 144 (1963).

215. Mendoza dealt with two cousolidated cases, one arising frons the deportation of an alien, and one arising from the failure of the State Department to issue a passport to allow an ex-citizen to return to the United States. In both cases the complamants lost their citizenship by remaining outside the jurisdiction of the United States to avoid military service in time of war or natural emergency. Id. at 147-52.

216. Flemming v. Nestor, 363 U.S. 603, 617 (1960); United States v. Lovett, 328 U.S. 303, 316 (1946); Ex parte Garland, 71 U.S. (4 Wall) 333, 377 (1866). 
inent, ${ }^{217}$ whether it comes into play only on a finding of scienter, ${ }^{218}$ whether its operation will promote the traditional aims of punishment-retribution and deterrence, 219 whether the behavior to which it applies is already a crime, ${ }^{220}$ whether an alternative purpose to which it may rationally be connected is assignable for it, ${ }^{21}$ and whether it appears excessive in relation to the alternative purpose assigned $^{222}$ are all relevant to the inquiry, and nuay often point in differing directions. Absent conclusive evidence of congressional intent as to the penal nature of a statute, these factors inust be considered in relation to the statute on its face. ${ }^{223}$

This analysis is helpful, although perhaps not conclusory, in characterizing the OSHA "civil penalties." The government would prefer to have these penalties treated as purely civil because the burden of proof and other procedural requirements are far less stringent in a civil proceeding than in a criminal proceeding. 224 The government should not, however, be able to alter an individual's constitutional guarantees, and the concomitant sanctions for a violation of these guarantees, such as the exclusionary rule, merely by labeling a proceeding as "civil" or "criminal." When determining the nature of the penalty, one inust look beyond the label and apply the Mendoza-Martinez analysis.

The key to the first consideration inentioned in Mendoza-Marti$n e z$, the "affirmative disability or restraint," is the "affirmative" nature of the penalty, because not every government action that is detrimental to an individual is necessarily "affirmative," although it may create a "disability." In two of the cases the Court cited to support this consideration, United States $v$. Lovett, ${ }^{225}$ and Ex parte Garland, ${ }^{226}$ the govern-

217. Wong Wing v. United States, 163 U.S. 228, 237-38 (1896); Mackin v. United States, 117 U.S. 348, 350-52 (1886); Ex parte Wilson, 114 U.S. 417, 426-29 (1885); Cummings v. Missouri, 71 U.S. (4 Wall.) 277, 320-21 (1866).

218. Child Labor Tax Case, 259 U.S. 20, $37-38$ (1922); Helwig v. United States, 188 U.S. 605, 610-12 (1903).

219. Trop v. Dulles, 356 U.S. 86, 96 (1958) (opinion of the Chief Justice); id. at 111-12 (Brennan, J., concurring); United States v. Constantine, 296 U.S. 287, 295 (1935).

220. United States v. Constantine, 296 U.S. 287, 295 (1935); United States v. LaFranca, 282 U.S. 568, 572-73 (1931); Lipke v. Lederer, 259 U.S. 557, 562 (1922).

221. Flemming v. Nestor, 363 U.S. 603, 615, 617 (1960); Trop v. Dulles, 356 U.S. 86, 96-97 (1958); United States v. LaFranca, 282 U.S. 568, 572 (1931); Lipke v. Lederer, 259 U.S. 557, 56162 (1922); Child Labor Tax Case, 259 U.S. 20, 43 (1922); Cummings v. Missouri, 71 U.S. (4 Wall.) 277, 319 (1866).

222. Rex Trailer Co. v. United States, 350 U.S. 148, 154 (1956); United States v. Constantine, 296 U.S. 287, 295 (1935); Helwig v. United States, 188 U.S. 605, 613 (1903); Cummings v. Missouri, 71 U.S. (4 Wall.) 277, 318 (1860). But see Flemming v. Nestor, 363 U.S. 603, 614, 616 n.9 (1960); Child Labor Tax Case, 259 U.S. 20, 41 (1922).

223. 372 U.S. at 168-69 (citations as in original; textual portions of original footnotes omitted). 224. See generally, Orfield, Burden of Proof and Presumptions in Federal Criminal Cases, 31 U. KAN. CitY L. Rev. 30 (1963).

225. 328 U.S. 303 (1946). 
inent action resulted in a permanent proscription on the individual's ability to pursue an occupation, and the Court found this to be the infliction of punishment. In the other case cited, Flemming v. Nestor, ${ }^{227}$ the government withheld social security benefits, and the court concluded that this was not punishment. The determinative distinction is between "passively" withholding a benefit and "affirmatively" inflicting a disability. The "civil penalties" of OSHA are much more "affirmative" than "passive" because they exact monetary retribution from the employer for violation of OSHA standards, as opposed to withholding a benefit, such as a government contract. ${ }^{228}$

The second Mendoza-Martinez consideration is the historical regard for the sanction as punishment. Before one can look for historical regard, however, one must determine whether and to what extent the sanction is a punishment. To garner some historical support for OSHA "civil penalties" as punishment, one must cngage in a two-part analysis: first, one must ask whether such penalties are "quasi-criminal"; and, second, whether "quasi-criminal" penalties are traditionally regarded as punishment. The Court of Appeals for the Tenth Circuit used this "quasi-criminal" approach in Savina Home Industries, Inc. v. Secretary of Labor, ${ }^{229}$ in which the court stated in dicta that it would extend the exclusionary rule to OSHRC proceedings because OSHA civil penalties are arguably "quasi-criminal."230 Significantly, the first case to consider the exclusionary rule, Boyd $v$. United States, ${ }^{231}$ was a "quasi-criminal" case. ${ }^{232}$ In One 1958 Plymouth Sedan v. Pennsylvania, ${ }^{233}$ the Supreme Court concluded that a forfeiture proceeding, although civil in naine, was im effect "quasi-criminal" because its object

226. 71 U.S. (4 Wall.) 333 (1866).

227. 363 U.S. 603 (1960).

228. Thus, for example, an action under the Walsh-Healy Act, 41 U.S.C. $\$ \S 35-45$ (1976), to bar a company from receiving a government contract for failure to have an acceptable affirmative action program probably would be. "civil."

229. 594 F.2d 1358 (10th Cir. 1979).

230. Id. at 1362 n.6. The court so concluded on the basis of the following definition of "quasicriminal" from Clark, Civil and Criminal Penalties and Forfeitures: A Framework for Constitutional Analysis, 60 MinN. L. Rev. 379, 381 (1976):

Laws that provide for punishment but are civil rather than criminal in form have sometimes been labeled "quasi-criminal" by the Supreme Court. These laws, broadly speaking, provide for civil money penalties, forfeitures of property, and the punitive imposition of various disabilities, such as the loss of professional license or public employment.

Id. (footnotes omitted).

231. 116 U.S. 616 (1886).

232. See text accompanying notes 50-52 supra.

233. 380 U.S. 693 (1965). 
was "to penalize for the commission of an offense against the law."234 The Court held that the exclusionary rule would apply in this type of "quasi-criminal" proceeding because

[i]t would be anomalous indeed, under these circumstances, to hold that in the criminal proceeding the illegally seized evidence is excludable, while in the forfeiture proceeding, requiring the determination that the criminal law has been violated, the sane evidence would be admissible. That the forfeiture is clearly a penalty for the criminal offense and can result in even greater punishment than the criminal prosecution has in fact been recognized by the Pennsylvania courts. 235

In other "civil" proceedings which bear a close identity to the objectives of criminal law enforcennent, such as juvenile delinquency proceedings, ${ }^{236}$ narcotics addict commitment proceedings, ${ }^{237}$ and civil actions for marijuana possession, ${ }^{238}$ courts have concluded that the "quasi-criminal" nature of the proceeding justifies the extension of the exclusionary rule. ${ }^{239}$ Thus, if a court concludes, as in Savina, that the

234. Id. at 700. The case concerned the forfeiture of an automobile that had been used for the illegal transportation of alcohol. The Court distinguished the forfeiture of narcotics in United States v. Jeffers, 342 U.S. 48 (1951) and the forfeiture of an unregistered still in Trupiano v. United States, 334 U.S. 699 (1948), because those cases involved contraband the possession of which was per se illegal. In the instant case, however, the possession of an automobile was not even arguably illegal. 380 U.S. at 698-70.

235. 380 U.S. at 701 (footnote omitted) (emphasis added). In a later case, One Lot Emerald Cut Stones v. United States, 409 U.S. 232 (1972), the Court distinguished Plymouth Sedan on the basis of the emphasized language. One Lot Emerald Cut Stones involved a forfeiture, pursuant to the tariff provisions of 19 U.S.C. $\S 1497$ (1976), of miported but undeclared merchandise. The forfeiture was civil; it did not depend on any showing of violation of the criminal law, 18 U.S.C. $\S$ 545 (1976), which prohibits such fraudulent importations.

236. See, e.g., In re Marsh, 40 Ill. 2d 53, 237 N.E.2d 529 (1968); $c$. Breed v. Jones, 421 U.S. 519 (1975) (double jeopardy violation to try one as an adult following prior adjudication of same offense in juvenile court); In re Winship, 397 U.S. 358 (1970) (proof beyond a reasonable doubt is required in juvenile proceedings for an act that would be a crime if committed by an adult); In re Gault, 387 U.S. 1 (1967) (juvenile entitled to Miranda warnings). See also Quick, Constifutional Rights in the Juvenile Court, 12 How. L.J. 76, 97 (1966). The exclusionary rule may not, howevcr, apply at the dispositional stage of the juvenile hearing, as opposed to the adjudication stage. See Comment, The Applicability of the Fourth Amendment Exclusionary Rule to Juveniles in Delinquency Proceedings, 4 Colum. Human Rights L. Rev. 417, 446 (1972).

237. See, e.g., People v. Moore, 69 Cal. 2d 674, 446 P.2d 800, 72 Cal. Rptr. 800 (1968).

238. See, e.g., State v. Barclay, 398 A.2d 794 (Me. 1979).

239. In the area of civil tax penalties, the result is less clear. In United States v. Janis, 428 U.S. 433 (1976), the Supreme Court refused to extend the exclusionary rule to a federal civil tax action to bar evidence illegally seized by state criminal law enforcement agents. The decision provoked the following comment from Justice Stewart in his dissent:

To be sure, the Elkins case was a federal criminal proceeding and the present case is civil

in nature. But our prior decisions make it clear that this difference is irrelevant for

Fourth Amendment exclusionary rule purposes where, as here, the civil proceeding

serves as an adjunct to the enforcement of the criminal law.

Id. at 463 (Stewart, J., dissenting) (citation omitted). The Court also distinguished Suarez v. Commissioner, 58 T.C. 792 (1972), in which the tax court applied the exclusionary rule. Other cases 
OSHA "civil penalties" are "quasi-criminal," historical support exists for treating such penalties as penal and for extending the exclusionary rule to the proceedings seeking to enforce them.

The third consideration of the Mendoza-Martinez test is "scienter." On the surface this consideration appears acceptable as a basis to distinguish civil and criminal penalties. In support of this consideration, the Court cited the Child Labor Tax Case, ${ }^{240}$ which involved the imposition of a "tax" equal to ten percent of the net income of a business if it employed a child in violation of the Child Labor Tax Law. ${ }^{241}$ If the employer could demonstrate, however, that he did not know the age of the child, he could escape the "tax." In striking down the tax as unconstitutional the Court explained that "[s]cienter is associated with penalties not with taxes."242 While the presence of scienter may be indicative of a penal sanction, the converse is not necessarily true. That is, the lack of scienter does not mean a sanction is not penal because not all penal offenses are malum in se. Many criminal statutes are mala prohibitum, making acts illegal only because they are legislatively prohibited. OSHA penalties, with the possible exception of willful violations, do not require scienter. ${ }^{243}$ Thus, in the strictest sense, the scienter consideration seems to militate against characterizing OSHA "civil penalties" as penal.

The fourth Mendoza-Martinez consideration is whether the operation of the penalty promotes the traditional aims of punishment and retribution associated with criminal statutes. This consideration is consistent with the dichotomy of purpose between civil actions, where the goal is remedial, and penal actions, where the objective is to pumsh and deter. OSHA imprisoument penalties ${ }^{244}$ are penal because they are aimed at the punishment and deterrence of individual einployers and because these penalties evoke the same kind of general deterrence associated with criminal statutes. OSHA abatennent orders ${ }^{245}$ and actions

have conclnded that civil tax cases are quasi-criminal. See, e.g., Pizzarello v. United States, 408 F.2d 579 (2d Cir. 1969); United States v. Blank, 261 F. Supp. 180 (N.D. Ohio 1966). See also Baade, Illegally Obtained Evidence in Criminal and Civil Cases: A Comparative Study of a Classic Mismatch II, 52 TEx. L. REv. 621 (1974).

240. 259 U.S. 20 (1922).

241. Pub. L. No. 65-254, tit. XII, $\S 1200,40$ Stat. 1057 (1919) (repealed 1921), which inter alia set the minimum age limits for various occupations and limited the number of hours per day and days per week which a child could work.

242. 259 U.S. at 37.

243. See, e.g., Kent Nowlin Const. Co. v. OSHRC, 593 F.2d 368 (10th Cir. 1979); Western Waterproofing Co. v. Marshall, 576 F.2d 139 (8th Cir.), cert. denied, 439 U.S. 965 (1978). See note 210 supra.

244. 18 U.S.C. \& 1114 (Supp. III 1979); 29 U.S.C. § 666(e)-(g) (1976).

245. 29 U.S.C. $\S 658$ (1976). 
to enforce them are remedial because they are intended to regulate and mold the future conduct of the specific employer.

The OSHA civil penalties appear to have both remedial and penal attributes. To the extent that they are incidental to the overall governmental goal of enhancing worker safety, they are regulatory. These penalties, however, are not merely an adjunct method of enforcing the purely civil abatement orders and accomplishing a regulatory goal. They are also methods of compelling compliance through their punitive effect. The primary purpose of thcse civil penalties is retributive because they focus on the employer's past offensive conduct. This latter consideration militates in favor of a penal characterization of OSHA sanctions. The overlapping, multiple purposes of these civil penalties, however, render this part of the test equivocal. ${ }^{246}$

The fifth Mendoza-Martinez consideration is whetler the conduct is already proscribed as a crime. The value of this consideration is limited to situations in whicl there is a separate criminal statute. The courts thus could conclude that the enactment of a distinctly separate civil prohibition was not intended to overlap with the penal nature of the criminal act, but was ineant as a remedial civil sanction. This reasoning is exemplified in One Lot Emerald Cut Stones v. United States, ${ }^{247}$ which upheld a civil forfeiture despite a criminal acquittal for the same conduct because the forfeiture did not require a showing of intent to defraud as did the criminal charge. 248 When no separate and distimct criminal statute exists, lowever, the benefit of comparison is nonexistent. That a criminal act does not coexist does not necessarily mean that the civil action has a penal purpose. In these situations this consideration is neutral. This situation typifies the posture of OSHA civil penalties, because for the most part ${ }^{249}$ there are no parallel criminal statutes.

The sixth part of the Mendoza-Martinez test is whether a rational alternative purpose is assigned to the penalty. In support of this consideration, the Court cited the Child Labor Tax Case, ${ }^{250}$ in whicls the Court drew an analogy to United States v. Doremus, 251 another tax

246. See generally Charney, The Need for Constitutional Protections for Defendants in Civil Penally Cases, 59 CoRnell L. Rev. 478 (1974).

247. 409 U.S. 232 (1972).

248. The Court noted that "the fact that the sanctions were separate and distinct and were contained in different parts of the statutory scheme is relevant in determining the character of the forfeiture. Congress could and did order both civil and criminal sanctions, clearly distinguishing them." Id. at 236.

249. The statute does provide criminal sanctions in certain situations. See note 210 supra.

250. 259 U.S. 20 (1922).

251. 249 U.S. 86 (1919). 
case. Doremus upheld a tax levied on the manufacture, importation, and sale of opium compounds or derivatives as being naturally and reasonably related to the government's taxing power. The possible existence of another motive, which did not appear on the face of the statute, such as control over the illegal narcotic trade, did not alter the civil nature of the tax penalty. ${ }^{252}$ The Mendoza-Martinez Court also cited Trop v. Dulles ${ }^{253}$ to support its analysis. In Trop the Court hypothesized a situation in which a bank robber loses both his liberty and his right to vote. The Court explained that the purpose of a statute, not its potential pumitive effect in certain situations, determines whetler it is penal or regulatory:

If, in the exercise of the power to protect banks, both sanctions were imposed for the purpose of punishing bank robbers, the statutes authorizing both disabilities would be penal. But because the purpose of the latter statute is to designate a reasonable ground of eligibility for voting, this law is sustained as a nonpenal exercise of the power to regulate the franchise. ${ }^{254}$

The Supreme Court will not, however, blind itself to the alternative purpose proffered by the government. In two prohibition-era tax cases, United States v. La Franca ${ }^{255}$ and Lipke v. Lederer, ${ }^{256}$ the Court noted that the only rational purpose in taxing illegal liquor was to suppress crime and thus the sanctions involved in those cases were held to be penal. 257

While the overall purpose of OSHA, to provide "safe and healthful working conditions and to preserve our human resources," 258 is a proper exercise of congressional authority, the specific purpose of the Act's civil penalties is to effectuate that overall goal through punitive or deterrent effect. No multiplicity of purpose problem hinders characterization. The sixth consideration thus supports recognition of the penal nature of the OSHA "civil penalty."

252. Id. at $93-94$.

253. 356 U.S. 86 (1958).

254. Id. at $96-97$ (footnote omitted).

255. 282 U.S. 568 (1931).

256. 259 U.S. 557 (1922).

257. Id. at 562. In La Franca the Court explained that the "tax" penalty imposed by the National Prohibition Act was a misnomer:

A tax is an enforced contribution to provide for the support of government; a penalty, as the word is here used, is an exaction imposed by statute as punishment for an unlawful act. The two words are not interchangeable, one for the other. No inere exercise of the art of lexicography can alter the essential nature of an act or a thing; and if an exaction be clearly a penalty it cannot be converted into a tax by the simple expedient of calling it such. That the exaction here in question is not a true tax, but a penalty involving the idea of punishment for infraction of the law is settled ....

282 U.S. at 572.

258. 29 U.S.C. $\S 651(b)(1976)$. 
The final part of the Mendoza-Martinez test asks whether the penalty appears excessive in relation to the alternative purpose assigned to the penalty. This consideration can be critical when the government avers that the penalty is ineant to be compensatory. Thus, in One Lot Emerald Cut Stones v. United States, ${ }^{259}$ the Court concluded that the monetary penalty of forfeiture was "a reasonable form of liquidated damages for violation of the inspection provisions and serves to reimburse the Government for imvestigation and enforcement expenses."260 The Court did recognize that there may be times when this "compensation" is so unreasonable that it transforms a civil remedy into a criminal penalty. ${ }^{261}$ If the OSHA civil penalties were merely a means of compensating the government for the expenses of enforcmg the Act and the penalties were reasonably related to those expenses, this consideration would support a characterization of the penalties as civil. The scale of OSHA penalties, however, is based on the severity of the infraction. ${ }^{262}$ The government apparently imcurs no greater expense im detecting a serious violation of the Act than a nonserious violation, but the penalty is drastically imcreased for the former. On balance, then, this consideration supports the penal nature of the civil penalties. ${ }^{263}$

Whether OSHA civil penalties are penal is ultimately a matter of statutory construction. ${ }^{264}$ If the intent of the penalty is punishment, "its character is not changed by the mode $m$ which it is inflicted, whether by a civil action or a criminal prosecution." 265 If the courts conclude that the sanction is penal, it should be subject to the same treatment as quasi-criminal proceedings in extending the exclusionary rule. The one certainty, however, is that the government may not use a talismanic

259. 409 U.S. 232 (1972).

260. Id. at 237.

261. Id.

262. See 29 U.S.C. $\& 666$ (1976).

263. There are other considerations not addressed in Mendoza-Martinez that affect the equation. For example, penalties for offenses against the authority of the government usually are peual. See Morissette v. United States, 342 U.S. 246, 256 (1952); Huntington v. Attrill, 146 U.S. 657, 667 (1892). Another consideration is whether the wroug invokes unoral condemnation by the comununity, but this consideration is too broad to be giveu nuch weight. See Hart, The Aims of the Criminal Laws, 23 LAw \& CoNTEMP. PROB. 401,404 (1958). One must also consider that the government is labeled the "plamtiff" in a "civil" action. This characterization does not lead to an inevitable conclusion, for even in an action by a private party, such as one for treble damages, the penalty can be peual. See Bowles v. Trowbridge, 60 F. Supp. 48 (N.D. Cal. 1945). A final consideration, which has been rejected by the Court in Trop is the form of the proceeding. Because a proceeding is not instigated by an indictment does not inean that its penalties are civil. Trop v. Dulles, 356 U.S. 86, 94-95 (1958). Sometimes a statute provides for a civil action by mdictment. See United States v. Stevenson, 215 U.S. 190 (1909). See generally Legislation-Statutory Penalties-A Legal Hybrid, 51 HARv. L. Rev. 1092 (1938).

264. See One Lot Emerald Cut Stones v. United States, 409 U.S. 232, 237 (1972).

265. United States v. Chouteau, 102 U.S. 603, 611 (1880). 
"civil" label coupled with a ritualistic reference to the United States $v$. Janis ${ }^{266}$ language that the Court has never apphed the exclusionary rule to civil proceedings ${ }^{267}$ in order to avoid the issue.

The Janis statement that the Supreme Court has never applied the exclusionary rule to civil proceedings does not change the fact that many state courts and administrative tribunals have, as a matter of policy, so applied it. Finn's Liquor Shop v. State Liquor Authority 268 applied the sanction in the hquor license revocation area. The New York Court of Appeals considered the revocation to be akin to a penalty for an offense against the law, rendering the administrative proceeding "quasi-criminal."269 The court lield that the deterrence rationale of $M a p p$ is as applicable to officials fulfilling regulatory functions as it is to law enforcement officials. ${ }^{270}$

In proceedings to revoke a professional license, the Supreine Court in In re Ruffalo ${ }^{271}$ held that such administrative proceedings are adversarial and quasi-criminal, requiring procedural due process for the licensee. ${ }^{272}$ This holding does not, however, answer the exclusionary rule applicability question. Sorne courts assume that the sanction apphes to these proceedings because of their deterrent nature and close identity to the objectives of criminal law enforcement. ${ }^{273}$ Other courts consider the extension of the rule to these proceedings inappropriate. ${ }^{274}$ The court in Emslie v. State Bar of California, ${ }^{275}$ for example, held that

266. 428 U.S. 433 (1976). See notes 160-64 supra and accompanying text.

267. Id. at 447.

268. 24 N.Y.2d 647, 249 N.E.2d 440, 301 N.Y.S.2d 584 (1969).

269. Id. at 654,249 N.E.2d at 442,301 N.Y.S.2d at 588 . The court rejected the contention that the government's function was only regulatory, with enforcement of the criminal law at most ouly a peripheral concern. The court held that state agencies, even if charged only with purely administrative responsibilities, were still required to conduct their "imvestigative and enforcement functions in compliance with constitutional requirements." Id., 249 N.E.2d at 442, 301 N.Y.S.2d at 588.

270. Id. at $653-54,249$ N.E.2d at $442-43,301$ N.Y.S.2d at 587-88. Similar holdings in other hiquor license revocation hearings include: LaPenta v. New York State Liquor Auth., 30 A.D.2d 1033, 294 N.Y.S.2d 947 (1968), affd, 24 N.Y.2d 647, 249 N.E.2d 440, 301 N.Y.S.2d 584 (1969); Leogrande v. State Liquor Auth., 25 A.D.2d 22S, 268 N.Y.S.2d 433 (1966); Pennsylvania Liquor Control Bd. v. Leonardziak, 210 Pa. Super. Ct. 511, 233 A.2d 606 (1967). Contra, Caniden County Beverage Co. v. Blair, 46 F.2d 648 (D.N.J. 1930).

271. 390 U.S. 544 (1968).

272. Id. at $550-51$.

273. E.g., Elder v. Board of Medical Examiners, 241 Cal. App. 2d 246, 50 Cal. Rptr. 304 (1966), cert. denied, 385 U.S. 1001 (1967).

274. See Pierce v. Board of Nursing Educ., 255 Cal. App. 2d 463, 63 Cal. Rptr. 107 (1967). The court did not fully explore the issue because it concluded that the evidence in question had been properly seized.

275. 11 Cal. 3d 210, 520 P.2d 991, 113 Cal. Rptr. 174 (1974). 
a balancing test must be applied in such proceedings and consideration must be given to the social consequences of applying the exclusionary rules and to the effect thereof on the integrity of the judicial process. . . . The application of such rules must be worked out on a case-by-case basis $\mathrm{m}$ this and other license revocation proceedings. ${ }^{276}$

The court concluded that there was practically no deterrent effect involved in the case and that the protection of the courts and of the integrity of the legal profession required that the evidence be introduced. ${ }^{277}$

Courts apparently take a similar case-by-case approach in public university and high school student expulsion hearings. Smyth v. Lubbers, ${ }^{278}$ a federal district court case, applied the exclusionary rule to a college disciplinary hearing. The college regulations required proof of a criminal law violation as the basis for expulsion, so the court analogized the proceeding to a One 1958 Plymouth Sedan $v$. Pennsylvania "quasi-criminal" action. ${ }^{279}$ Focusing on the rule's deterrent effect, the court concluded that in the absence of the sanction, the college authorities would have no incentive to respect the privacy of students. ${ }^{280}$ In Caldwell v. Cannady 281 the Federal District Court for the Northern District of Texas extended this reasoning to a high school disciplinary hearing. Based on the combined principles of Tinker v. Des Moines Independent Community School District, ${ }^{282}$ that students lose none of their constitutional rights because of their status as students, and Coolidge v. New Hampshire, ${ }^{283}$ that any search without the prior approval of a magistrate is per se unreasonable, the court prohibited the school board from considering illegally obtained evidence. ${ }^{284}$ In Morale $\nu$. Grigel, 285 however, another federal district court refused to extend the sanction to a college disciplinary hearing because it believed that the Supreme Court had limited the rule to criminal proceedings. ${ }^{286}$

276. Id. at 229-30, 520 P.2d at 1002, 113 Cal. Rptr. at 186 .

277. Id. at 229, 520 P.2d at 1002, 113 Cal. Rptr. at 186.

278. 398 F. Supp. 777 (W.D. Mich. 1975).

279. See notes 233-35 supra and accompanying text.

280. 398 F. Supp. at 794.

281. 340 F. Supp. 835 (N.D. Tex. 1972).

282. 393 U.S. 503 (1969).

283. 403 U.S. 443 (1971).

284. 340 F. Supp. at 839. See also Moore v. Student Affairs Comm., 284 F. Supp. 725 (M.D. Ala. 1968), which also addresses the issue but does not decide it because the search in question was held not to violate the fourth amendment.

285. 422 F. Supp. 988 (D.N.H. 1976).

286. Id. at 1001. See also Ekelund v. Secretary of Commerce, 418 F. Supp. 102 (E.D.N.Y 1976), $\mathrm{m}$ which the court refused to apply the rule in a midshipman disciplinary proceeding at the Umited States Merchant Marine Academy. The court held that

the use of the evidence discovered in the search in the disciplinary proceeding must be considered in light of the fact that it is a civil proceeding. The consequences of the 
Some courts have equated the termination of a public employee's service with a "penal sanction" and have, therefore, applied the rule in those situations. ${ }^{287}$ In Board of Selectmen v. Municipal Court ${ }^{288}$ the Massachusetts Supreme Court applied the exclusionary rule to a proceeding brought to discharge a police officer. The court noted that

[i]n the present case the government is opposing the individual in a noncriminal milieu; this is not a purely civil proceeding by one private party against another. We pass the deterrence function since we think "judicial integrity" is at stake in the sense that the government is seeking to take advantage of its own lawbreaking to punish the victim of that illegality. ${ }^{289}$

The court also considered the necessity of preserving public confidence in government processes and held the sanction applicable as a natter of state law without definitively determining whether federal law also required its application. ${ }^{290}$ One state appellate court, however, refused to extend the rule to a teacher dismissal proceeding despite its admittedly punitive character. ${ }^{291}$ The court noted that the "judicial integrity" rationale is appropriate for civil cases, but expressed doubt about the appropriateness of the "deterrence" rationale to civil proceedings. ${ }^{292}$ Because the primary purpose of the teacher dismissal proceeding was to protect the pupils, and as the action was for immoral conduct, the court concluded that the rule should not be applied. The court did not decide the applicability of the rule to proceedings to discipline a teacher on nonmoral grounds or to proceedings to discipline nembers of professions generally. ${ }^{293}$

In alien deportation hearings, courts assuned that the exclusionary rule applied ${ }^{294}$ because aliens are entitled to fourth amendment

proceeding are grave, but it is not a criminal proceeding, and in no true sense is the proceeding punitive or vindictive, nor is it a forfeiture proceeding. Rather it is a determimation of unfitness for training for command rank in the inerchant marine. In such a case the use in evidence of that which might be excluded in a criminal case does not involve an invasion of a constitutionally protected interest.

Id. at 106 .

287. See, e.g., Powell v. Zuckert, 366 F.2d 634 (D.C. Cir. 1966); Saylor v. United States, 374 F.2d 894 (Ct. Cl. 1967); Rinderknecht v. Maricopa City Einployees Sys., 111 Ariz. 174, 526 P.2d 713 (1974); Gaglia v. Starr, 59 A.D.2d 839, 398 N.Y.S.2d 898 (1977).

288. 369 N.E.2d 1145 (Mass. 1977).

289. Id. at 1147 .

290. Id. at 1148 .

291. Governing Bd. v. Metcalf, 36 Cal. App. 3d 546, 111 Cal. Rptr. 724 (1974).

292. Id. at 549, 111 Cal. Rptr. at 726.

293. Id. at 551, 111 Cal. Rptr. at 728. See also City of New Brunswick v. Speiglits, 157 N.J. Super. 9, 384 A.2d 225 (Middlesex County Ct. 1978); People v. McGrath, 46 N.Y.2d 12, 385 N.E.2d 541, 412 N.Y.S.2d 801 (1978).

294. See United States v. Wong Quong Wong, 94 F. 832 (D. Vt. 1899), im which the court applied the sanction to such a hearing based on the same intertwining of the fourth and fifth amendinents created in Boyd. See also Ex parte Jackson, 263 F. 110 (D. Mont. 1920), which 
protection. ${ }^{295}$ This assumption about the applicability of the exclusionary rule to deportation hearings arises from language in Bilokumsky $v$. Tod, ${ }^{296}$ in which the Supreme Court stated: "It may be assumed that evidence obtained by the Department through an illegal search and seizure cannot be made the basis of a finding in deportation proceedings."297 This assumption went relatively unquestioned until Smith $v$. Morris, ${ }^{298}$ where a federal district court held the sanction to be inapplicable to a deportation hearing in which the only issues were the identity and status of the alien, not his past conduct. ${ }^{299}$ The Board of Immigration Appeals also has begun to adopt this approach. In In re Sandoval ${ }^{300}$ the Board determined that because deportation proceedings have traditionally been characterized as civil, ${ }^{301}$ it would not, postJanis, apply the sanction, because application would not increase any deterrent effect. 302

The exclusionary rule has been applied to administrative agencies, such as the Federal Trade Commission in its proceedings to enforce regulatory schemes. ${ }^{303}$ In Federal Trade Commission v. Page, ${ }^{304}$ a federal district court distimguished United States v. Calandra ${ }^{305}$ from Silverthorne Lumber Co. v. United States:306 "Calandra may be interpreted as recognizing an investigative exception to the exclusionary

appears to have the same basis because the court held the proceeding to be unfair and invalid in that it was "based upon evidence and procedure that violate the search and seizure and due process clauses of the Constitution." Id. at 112-13.

295. See, e.g., Au Yi Lau v. Immigration and Naturalization Serv., 445 F.2d 217 (D.C. Cir. 1971). See also Schenck ex rel. Chow Fook Hong, 24 F. Supp. 776 (D. Mass. 1938), in which the court stated:

It is well settled that aliens while in the United States are entitlcd to the protections of the Constitution and evidence obtained by the government in violation of a person's rights secured by the Fourth Amendinent is not admissible against him in criminal proceedings. This principle of law has been extended to civil cases as well.

Id. at 778 (citations omitted).

296. 263 U.S. 149 (1923).

297. Id. at 155 (comparing Silverthorne Lunber Co. v. United States, 251 U.S. 385 (1920) with Gouled v. United States, 255 U.S. 298 (1921)).

298. 442 F. Supp. 712 (E.D. Pa. 1977).

299. For an analysis of the reappraisal in this area, see generally Fragoinen, Searching for Illegal Aliens: The Immigration Service Encounters the Fourth Amendment, 13 SAN DiEGO L. REV: 82 (1975); Wasserman, Grounds and Procedures Relating to Deportation, 13 SAN DIEGo L. REv. 125 (1975).

300. No. 2725 (Bd. Immigration App. Aug. 20, 1979).

301. See Harisiades v. Shaughnessy, 342 U.S. 580, 594 (1952).

302. In re Sandoval, No. 2725, ship op. at 9-10. See Note, In re Sandoval: Deportation and the Exclusionary Rule, 58 N.C.L. Rev. 647 (1980). See generally Fragoinen, Procedural Aspects of Illegal Search and Seizure in Deportation Cases, 14 SAN DiEgo L. Rev. 151 (1976).

303. See Knoll Assocs. v. Federal Trade Comm'n, 397 F.2d 530 (7th Cir. 1968).

304. 378 F. Supp. 1052 (N.D. Ga. 1974).

305. 414 U.S. 338 (1974). See text accompanying notes 153-64 supra.

306. 251 U.S. 385 (1920). 
rule: that is, the fourth ainendment inay not be used to prevent investigative institutions from determining whether there is cause to believe that violations of the law have occurred."307 The proceeding in question, however, was adjudicative, rather than investigative, because a complaint had already issued. ${ }^{308}$ The rule also has been applied, or been assumed apphicable, in a Securities and Exchange Commission proceeding, ${ }^{309}$ a utilities termination hearing, ${ }^{310}$ an action to remove a judge, ${ }^{311}$ a civil action to recover penalties for violation of municipal zoning ordinances, ${ }^{312}$ abatement of nuisance proceedings, ${ }^{313}$ a civil proceeding to enjoin the future showing of an allegedly obscene film, ${ }^{314}$ and even a treble damages antitrust action. ${ }^{315}$ In certain areas, such as guardianship proceedimgs, the exclusionary rule has been held inappropriate; ${ }^{316}$ in others, such as National Labor Relations Board hearings, the rule's status is uncertain. ${ }^{317}$ Finally, cases involving illegal searches by the government that result in a private litigant using the fruits of the illegal search im private litigation ${ }^{318}$ and illegal searches by private in-

307. 378 F. Supp. at 1057 (footnote omitted).

308. This determination is consistent with a finding that a state commission investigating organized crime need not apply the sanction. See Catena v. Seidl, 66 N.J. 32, 327 A.2d 658 (1974).

309. OKC Corp. v. Williams, 461 F. Supp. 540 (N.D. Tex. 1978).

310. Goldin v. Public Util. Comm'n, 23 Cal. 3d 638, 592 P.2d 289, 153 Cal. Rptr. 802 (1979).

311. Sarisohn v. Appellate Division, 21 N.Y.2d 36, 233 N.E.2d 276, 286 N.Y.S.2d 255 (1967).

312. Incorporated Village of Laurel Hollow v. Laverne, Inc., 24 A.D.2d 615, 262 N.Y.S.2d 622 (1965); see 50 CORNELL L.Q. 282 (1965).

313. Carlisle v. State, 276 Ala. 436, 163 So. 2d 596 (1964); Carson v. State, 221 Ga. 299, 144 S.E.2d 384 (1965); Parish of Jefferson v. Bayou Landing, Ltd., 350 So. 2d 158 (La. 1977).

314. State v. Spoke Comm., 270 N.W.2d 339 (N.D. 1978).

315. Iowa v. Union Asplialt \& Roadoils, Inc., 281 F. Supp. 391 (S.D. Iowa 1968), affd sub nom. Standard Oil Co. v. Iowa, 408 F.2d 1171 (8th Cir. 1969).

316. In re Christoplier B., 82 Cal. App. 3d 608, 147 Cal. Rptr. 390 (1978); In re Robert P., 61 Cal. App. 3d 310, 132 Cal. Rptr. 5 (1976).

317. In NLRB v. Bell Oil \& Gas Co., 98 F.2d 870 (5th Cir. 1938), the court noted that "[i]f the Board sliould base its findings solely upon evidence obtained by an unconstitutional searcli, the order resting thereon would be invalid, because sucl evidence is incompetent." $I d$ at 871 . NLRB v. South Bay Daily Breeze, 415 F.2d 360 (9th Cir. 1969), lowever, stands for the proposition that the sanction does not apply in Board proceedings. That holding is limited, lowever, because the search at issue was conducted by a private individual.

318. The use of illegally obtained evidence in private litigation is of particular concern in areas suclı as arson wlere, after Michigan v. Tyler, 436 U.S. 499 (1978), insurance companies were concerned that illegal government searclies after a fire would result in the imsurance companies being unable to use the evidence to defend suits seeking payment under insurance policies. See Denenberg \& Gordon, The Exclusionary Rule in Civil Litigation: Sifting Through the Ashes of Michigan v. Tyler, 47 INs. Counsel J. 375 (1980). Sone courts liave excluded the use of sucli evidence, see, e.g., Lebel v. Swincicki, 354 Mich. 427, 93 N.W.2d 182 (1958); Kassner v. Frenront Mutual Ins. Co., 47 Micl. App. 264, 209 N.W.2d 490 (1973); People v. Dajnowicz, 43 Mich. App. 465, 204 N.W.2d 281 (1972), while other courts have admitted sucl evidence, see, e.g., Honeycutt v. Aetna Ins. Co., 510 F.2d 340 (7th Cir.), cert. denied, 421 U.S. 1011 (1975); Carey v. Zayre of Beverly, Inc., 367 Mass. 125, 324 N.E.2d 619 (1975). 
dividuals for use in criminal ${ }^{319}$ or private litigation ${ }^{320}$ offer limited analytical support either for or against the application of the exclusionary rule in OSHRC proceedings.

To the extent that OSHRC hearings can result in fines or imprisonment, they are akin to criminal trials. Even in criminal trials, however, the courts draw boundary lines between the trial proper and pretrial/post-trial phases or proceedings. For example, the Supreme Court has refused to mclude the sanction in grand jury proceedimgs ${ }^{321}$ or preliminary hearings ${ }^{322}$ because the additional deterrent effect is not sufficiently significant to justify interfering with these investigative proceedings. Similarly, courts have refused to extend the exclusionary rule to the sentencing phase of criminal trials, ${ }^{323}$ thus enabling the judge to fashion an appropriate sentence based on all relevant evidence. ${ }^{324}$ Courts have been receptive, however, to applying the exclusionary rule to sentencing proceedings if the government illegally seized the evidence specifically to use it to increase the sentence. ${ }^{325}$ The justification for this exception is that it will deter the potential official misconduct of coinpding a dossier to be used at sentencing. The courts also, as a general rule, refuse to extend the exclusionary rule to parole or probation revocation hearings. ${ }^{326}$

319. Burdeau v. McDowell, 256 U.S. 465 (1921), is still good law for admitting the evidence in this situation.

320. See, e.g., Sackler v. Sackler, 15 N.Y.2d 40, 203 N.E.2d 481, 255 N.Y.S.2d 83 (1964) (such evidence admissible); Williams v. Williams, 8 Ohio Misc. 156 (1966) (such evidence inadmissible). See generally Sutherland, Use of Illegally Seized Evidence in Non-Criminal Proceedings, 4 Crum. L. BuLL. 215 (1968).

321. United States v. Calandra, 414 U.S. 338 (1974).

322. Giordenello v. United States, 357 U.S. 480 (1958). See also FED. R. CRIM. P. 5.1.

323. See, e.g., United States v. Schipani, 315 F. Supp. 253 (E.D.N.Y.), aff d, 435 F. $2 d 26$ (2d Cir. 1970), cert. denied, 401 U.S. 983 (1971); Von Pickrell v. People, 163 Colo. 591, 431 P.2d 1003 (1967).

324. See Williams v. New York, 337 U.S. 241 (1949), where the Court noted that "modern concepts individualizing punishment have made it all the noore necessary that a sentencing judge not be denied an opportunity to obtain pertinent information by a requirement of rigid adherence to restrictive rules of evidence properly applicable to the trial." Id. at 247.

325. See Verdugo v. United States, 402 F.2d 599 (9th Cir. 1968); State v. Banks, 157 N.J. Super. 442, 384 A.2d 1164 (Super. Ct. Law Div. 1978); ff. People v. Belleci, 24 Cal. 3d 879, 598 P.2d 473, 157 Cal. Rptr. 503 (1979) (holding that the sentencing phase of a prosecution was a hearing within the purview of a state statute which prohibits the use of evidence against an individual in any hearing once a suppression motion has been granted).

326. The majority view is that the exclusionary rule inhibits the parole or probation systens from accomplishing their reinedial objectives. See, e.g., United States v. Brown, 488 F.2d 94 (5th Cir. 1973); United States v. Hill, 447 F.2d 817 (7th Cir. 1971); Sperling v. Fitzpatrick, 426 F.2d 1161 (2d Cir. 1970). The minority view, however, uniformly applies the exclusionary rule to these proceedings. See, e.g., United States v. Workman, 585 F.2d 1205 (4th Cir. 1978); Michaud v. State, 505 P.2d 1399 (Okla. 1973); Cantu v. State, 557 S.W.2d 107 (Tex. Crim. App. 1977) (dicta). 
Because OSHRC proceedings do not have the structure of traditional criminal proceedings, it is extremely difficult to demarcate the stages of the proceedings in which the sanction would or would not be applicable based on a comparison with the stages of criminal proceedings. The OSHRC hearing is an integrated proceeding to determine both the existence of a violation and the nature and amount of the penalty. The comphance officer must perceive that any evidence uncovered by his inspection will be considered in both the violation and the penalty aspects of the proceedings, which may inake the deterrence argument even stronger in the OSHA context. If the exclusionary rule is to apply, it should encompass the entire proceeding.

The OSHRC must evaluate the nature of the penalties and the character of its proceedings to determine if an extension of the sanction is appropriate. While the OSHA function may be regulatory, the OSHRC hearing is no more "investigative" than is any court attempt to determine whether violations of the law exist. The purpose of the OSHRC is to determine both violation and penalty. The penalties, having both certain penal and civil aspects, appear on balance to be "quasi-criminal." Also, even though as an administrative tribunal the OSHRC may not be required to extend the sanction, it is certainly within its prerogative to do so as a matter of its own policy. In so doing, the OSHRC must balance the societal harm of having no sanction against the ability of the rule to further the purposes enunciated by the courts.

\section{The Purposes of the Exclusionary Rule IN The OSHA CONTEXT: Policy CONSIDERATIONS}

Although the proponents of the exclusionary rule have postulated inany cogent justifications for the sanction, its critics, encouraged by popular hostility toward the rule, have increased the pressure to jettison the rule entirely. The admitted lack of convincing einpirical data places each side in the uncomfortable position of attempting to justify its rationale without a solid factual basis. The OSHRC should consider carefully all of the purported benefits and costs of the sanction, which for the most part have been articulated in the criminal arena, and determine if on balance the purposes of the rule will be furthered by extending it to OSHRC hearimgs.

Some jurisdictions do not apply the exclusionary rule unless bad faith is established. See, e.g. , State v. Shirley, 117 Ariz. 105, 570 P.2d 1278 (Ct. App. 1977); Dickson v. State, 124 Ga. App. 406, 184 S.E.2d 37 (197I); State v. Proctor, 16 Wash. App. 865, 559 P.2d I363 (1977). 
The OSHRC should focus initially on the beneficiaries of the rule. The popular conception of the operation of the rule, that an obviously guilty person goes free and neither the victin nor society gains anything, overlooks an important consideration: the victim and society are the principal beneficiaries of the intangible protection against unreasonable invasions of privacy. ${ }^{327}$ The rule is intended to unaintain popular respect for the legal systen and not to benefit the particular defendant, although he is an ancillary beneficiary of the rule. ${ }^{328}$ This societal benefit is as apphicable to an OSHRC hearing as it is to a criminal proceeding; the rule would protect all einployers and society. The particular employer "benefits" only to the same extent as a criminal defendant; the "victims," such as the employees, suffer no inore than victims or society in general when the rule is used in the criminal sphere.

The application of the rulc to OSHRC proceedings would cnhance the professionalism of the coinphiance officers by offering them a ineaningful imcentive to keep abreast of the warrant requireınents. ${ }^{329}$ Adınitting evidence obtained froin a warrant based on an erroneous, albeit good faith, factual or legal basis rewards coinpliance officers' ignorance. The requireinents for administrative search warrants are not as stringent as those for criminal warrants, and coinphance officers can meet these requirements witl far less difficulty than their law enforcement counterparts. Comphance officers are seldoin faced with the exigent circumstances confronting police officers, who inust often act on the spur of the inoment.

If the government atteinpts to establish a broad 'good faith' exemption for defective warrants on the basis of Michigan v. DeFillippo, ${ }^{330}$ it would be unsupportable. If a coinpliance officer relies in good faith on a procedure later declared unconstitutional, as was done im DeFillippo, ${ }^{331}$ then the rule should apply. The government can hardly extrapolate from this case that if a complance officer relies in

327. See Dworkin, Fact Style Adjudication and the Fourth Amendment: The Limits of Lawyering, 48 IND. L.J. 329, 330-31 (1973).

328. See, e.g., Traynor, Mapp v. Ohio at Large in the Fifty States, 1962 DuKE L.J. 319, 335.

329. This incentive is materially different froon the purported social benefits of avoiding any insult to police professionalism by abandoning the sanction in the criminal context. That argument envisions a rejection of an existing exclusionary rule as having a concomitant chastisement of the police by insinuating that the courts have given up on the ability of the police to conform their conduct to constitutional standards. See generally Geller, Enforcing the Fourth Amendment: The Exclusionary Rule and Its Allernatives, 1975 WASH. U.L.Q. 621.

330. 443 U.S. 31 (1979).

331. Id. at 34. The Court concluded that evidence obtained from a search following an arrest under a presumptively valid ordinance was admissible even though the ordimance was later held to be unconstitutionally vague. 
good faith on a warrant that is later declared defective due to a factual or legal deficiency, rather than a change in the law, he should be excused. Among the problems that can easily be envisioned is that compliance officers could engage in magistrate shopping based on which magistrate is more likely to issue a warrant on weak probable cause. Additionally, the "good faith" of the compliance officer necessarily depends on the officer's state of mind, which is determined from his selfserving and generally uncontradicted testimony. ${ }^{332}$

A societal benefit conceded even by the critics of the sanction in the criminal sphere ${ }^{333}$ is that application of the exclusionary rule to OSHRC proceedings would give the OSHRC, and later the appellate courts, numerous opportunities to scrutinize the operations of compliance officers and to articulate meaningful constitutional standards. The increased attention would produce greater clarity of substantive requirements and more effective communication of tlose requirennents to the compliance officers.

One criticism of the sanction is that the "prosecutor" is "punislied" because he loses his case. This argument is as weak as the "criminal goes free because the constable has blundered" argument, because it has an incorrect focus. The function of a prosecutor, as well as that of a Labor Department attorney, is the vindication of the societal interest. The balance is not between the compliance officer and the lawbreaking employer, but between two types of lawbreakers. ${ }^{334}$

A more convincing criticism is that the sanction is too rigid. ${ }^{335} \mathrm{Se}-$ rious and flagrant imtrusions lead to the same exclusion of trustworthy evidence as do trivial and unintentional invasions. The inflexible nature of the sanction offends one's sense of proportion. ${ }^{336}$ Critics claim that when the public perception of justice is so offended the judicial integrity purpose disintegrates, because the actual effect is the loss of public respect for the law and the judiciary. ${ }^{337}$ The response to this

332. See generally Kaplan, The Limits of the Exclusionary Rule, 26 STAN. L. REv. 1027, 104445 (1974). But see Ball, Good Faith and the Fourth Amendment: The "Reasonable" Exception to the Exclusionary Rule, 69 J. CRIM. L. \& CRIMINology 635 (1978).

333. Paulsen, The Exclusionary Rule and Misconduct by the Police, 52 J. CRIM. L.C. \& P.S. 255,260 (1961).

334. See Dworkin, supra note 327, at 330.

335. See, e.g., Burger, Who Will Watch the Watchman?, 14 AM. U.L. Rev. 1,12 (1967); Burns, Mapp v. Ohio, An All-American Mistake, 19 DE PAUL L. Rev. 80 (1969).

336. One commentator has analogized this aspect of the exclusionary rule to the criminal sanctions of Victorian England where all felons, from murderers to pickpockets, received the same punishment: hanging. Baker \& Corrigan, Making the Constable Culpable: A Proposal to Improve the Exclusionary Rule, 27 HASTINGS L.J. 1291, 1296 (1976).

337. See, e.g., Coe, The ALI Substantiality Test: A Flexible Approach to the Exclusionary Sancsion, 10 GA. L. REv. 1 (1975). 
criticism is that no intrusion of the privacy interest is "trivial" or "inconsequential" and, more basically, this mflexibility is the key to the rule's effectiveness as a deterrent. ${ }^{338}$ As soon as flexibility is mcorporated into the equation there is another avenue of trial court nullification and an increased temptation for officers to see how far they can bend the rule without breaking it. ${ }^{339}$ A corollary to the "flexibility" argument is the proposal to limit the rule to "non-serious" cases. The problem with such an approach is that the removal of the "serious" cases also removes the rule's greatest deterrent impact. 340

That societal costs result from the distortion of the fact-findimg process by excluding highly probative and trustworthy evidence is probably the most meritorious criticism of the exclusionary rule. The collateral issue of the compliance officer's conduct shifts the focus of the OSHRC hearing away from the ultimate issue of the einployer's alleged violations. The potential for delay is greatly increased. The critics suggest having the violation of the employer's rights vindicated im an appropriate and separate forum. ${ }^{341}$ If, after balancing the societal costs and benefits, the OSHRC reaches no clear conclusion about the rule's applicability, it must determine whether effective alternatives to the rule exist in the OSHA sphere.

The single most effective way for OSHA to avoid the exclusionary rule is to convince the OSHRC that adequate alternative remedies are available, either singularly or in combimation, or that OSHA can develop and implement its own deterrent policies. These alternatives, existing or proposed, generally fall within four inajor categories: a civil action against the offendimg officer personally or against the government; a criminal action against the offending officer; internal depart-

\footnotetext{
338. This analysis is advanced by one commentator who explains that:

In an area where conduct control is a major policy, consistency seems preferable to flexibility, as one can hardly expect individuals to conform their conduct to unannounced, unpredictable norms. ...

The exclusionary rule, or any deterrent sanction, must fail if the law it is designed to enforce is tentative, flexible, and self-consciously oriented to facts. To effectively deter pohice misconduct the Court must develop inflexible categories and clear rules.

Dworkin, supra note 327 , at 365 .
}

339. The inflexibility of the sanction las also been criticized as encouraging unlawful police conduct, such as perjury, to avoid the rule. See, e.g., Sevilla, Exclusionary Rule and Police Perjury, 11 San Diego L. Rev. 839 (1974); Comment, Police Perjury in Narcotics "Dropsy" Cases: A New Credibility Gap, 60 GEO. L.J. 507 (1971).

340. The criticism does, however, lave a certain alluring clarm in that by removing the judicial concern with the prospect of freeing "serious" criminals, the courts could interpret the parameters of the fourth amendment more fully and honestly. Sce Kaplan, The Limits of the Exclusionary Rule, 26 STAN. L. REv. 1027, 1046-50 (1974).

341. See generally Levin, An Alternative to the Exclusionary Rule for Fourth Amendment Violations, 58 JudicATURE 74 (1974). 
mental disciplinary proceedings and/or external review boards; and mjunctive relief.

The idea of an effective civil remedy based in tort is not new. ${ }^{342}$ Many of the abuses which justify the exclusionary rule are actionable in state courts as common law torts. ${ }^{343}$ The state court may impose personal liability on the officer and/or respondeat superior liability on the state or municipality. The Civil Rights Act ${ }^{344}$ provides a cause of action depending on the existence of the requisite state action and colorable authority. The municipality or state would be liable in addition to the individual officer, and attorney fees are recoverable. ${ }^{345}$ Every common law offense, however, is not necessarily a civil rights violation, and a plaimtiff would still have to deal with the "qualified immunity" 346 and "good faith" 347 defenses. Additionally, the "constitutional tort," developed in Bivens v. Six Unknown Named Agents, ${ }^{348}$ permits suit in federal court for violations of the fourth amendinent by OSHA officers. The government may imdemnify an officer or carry insurance to cover his liability for constitutional or common law torts, but it is extremely doubtful that a judicial decree could extend liability to the federal government itself, as this extension is more properly within the purview of Congress. 349

The replacement of the exclusionary rule with an effective tort remedy is a popular alternative among most critics of the exclusionary sanction. 350 Chief Justice Burger in his Bivens dissent suggested that

342. See, e.g., Bell v. Hood, 327 U.S. 678 (1946).

343. See generally Foote, Tort Remedies for Police Violations of Individual Rights, 39 MiNN. L. REv. 493 (1955).

344. 42 U.S.C. \& 1983 (Supp. III 1979).

345. 42 U.S.C. $\$ 1988$ (1976).

346. See Monroe v. Pape, 365 U.S. 167 (1961). See also Laverne v. Corning, 522 F.2d 1144 (2d Cir. 1975) (qualified immunity extended to a building inspector who had conducted a warrantless inspection).

347. See Pierson v. Ray, 386 U.S. 547 (1967). This defense involves both the snbjective element of aetual good faith and the objective element of a reasonable behef.

348. 403 U.S. 388 (1971). See generally Dellinger, Of Rights and Remedies: The Constitution as a Sword, 85 HARv. L. REv. 1532 (1972); Lehmann, Bivens and Its Progeny: The Scope of a Constitutional Cause of Action for Torts Committed by Government Officials, 4 HASTINGS CoNST. L.Q. 531 (1977).

349. See 28 U.S.C. $\& 2680$ (h) (1976) (amendment to Federal Tort Claims Act making the governinent liable for certain common law torts committed by law enforcement officers).

350. See Oaks, Studying the Exclusionary Rule in Search and Seizure, 37 U. CHI. L. REV. 665 (1970). The author supports the tort alternative:

A practical tort remedy would give courts an occasion to rule on the content of constitutional rights . . . and it would provide the real consequence needed to give credibility to the guarantee. A tort remedy could break free of the narrow compass of the exclusionary rule, and provide a viable remedy with attendant direct deterrent effect upon the police whether the injured party was prosecuted or not. Id. 757. 
the abolition of the exclusionary rule could be compensated for by the enactment of a statute which would: waive sovereign immumity; create a cause of action for fourth amendment violations; create a quasi-judicial tribunal to adjudicate the claims; be used in heu of the exclusionary rule; and eliminate the exclusionary rule for fourth amendment violations. ${ }^{351}$ The Department of Labor could, of course, seek such an amendment to the Act froin Congress as a method of convincing the OSHRC not to adopt an exclusionary rule. The effectiveness, however, of such alternative reinedies is doubtful. The einployer who has been caught in the act of violating the law by endangering the health and safety of his employees is not a natural object of sympathy when he seeks damages froin an overzealous coinpliance officer or OSHA. ${ }^{352}$ Litigation costs also inay hinder the effectiveness of the tort remedy. If the proposed civil penalty is relatively small, inost employers would have little incentive to pursue costly tort litigation in which the chance of success is speculative. If employers pursue the remedy only infrequently or if the awards are insubstantial, the deterrent effect on the compliance officer is minimal. The deterrent effect is reduced further if the compliance officer is either indemnified or judgment proof. ${ }^{353}$ Without significant recovery potential, employers, particularly small employers, may even encounter difficulty retaining counsel. ${ }^{354}$ A further difficulty with depending on tort remedies is that the government slould not be allowed to purchase an individual's constitutional rights. Despite these practical probleuns, the tort remedies should not be abandoned, but neitler should they be the sole means of protecting the employer's fourth amendment rights.

Criminal prosecutions against offending police officers are infrequent for obvious reasons. Prosecutors are reluctant to charge overzealous police officers, particularly if the police action lias resulted in the detection or prevention of crime. Criminal sanctions are not adequate protection for employers' fourth amendment rights due to the infrequency of sucli actions and because einployers cannot have these prosecutions on demand, but lave to depend on the discretion of the

351. 403 U.S. at $422-23$.

352. Cf. Project, Suing the Police in Federal Courts, 88 YALE L.J. 781, $782-88$ (1979) (juries are biased in favor of police defendants in suits brought by plaimtiffs alleging police misconduct).

353. See generally Foote, Tort Reunedies for Police Violations of Individual Rights, 39 MiNN. L. REv. 493 (1955).

354. This dilemma has also been proffered in the criminal splere because a practitioner may hesitate to engage in such suits for fear of obtaining a reputation as being antagonistic to police officers. This reputation could liamper his relationship with the police force which may be critical in other plases of this practice, for example, the personal injury specialist who depends leavily on police accident reports. 
Department of Justice. ${ }^{355}$ Nevertheless, certain criminal statutes exist that may have at least an incremental deterrent effect on law enforcement officials and, if properly communicated to them, on compliance officers as well. These offenses include willfully depriving a person of a federal right, ${ }^{356}$ willfully exceeding one's authority or exercising it with unnecessary severity in executing a search warrant, ${ }^{357}$ securing a search warrant maliciously and without probable cause, ${ }^{358}$ and maliciously and without probable cause searching a building without a search $w 2$ irant. ${ }^{359}$ Although these statutes apply to compliance officers as federal officials, the criminal element of specific intent ${ }^{360}$ renders them nugatory in the vast majority of cases. ${ }^{361}$ One can assume that there is no pervasive maliciousness among compliance officers and that their transgressions are based on errors of judgment or lack of knowledge of fact or law. Criminal sanctions therefore provide minimal deterrent effect and do not provide a significant alternative to the exclusionary rule. ${ }^{362}$

Internal disciplinary proceedings answer one of the sharpest criticisms of the exclusionary rule by clearly and effectively communicating to the target population the reasons for the sanction and the rules to be followed in order to comply with the fourth amendment. An important ancillary effect of the exclusionary rule is to stimulate the police to increase their professionalism and improve their own compliance standards.363 The current judicial process of suppression hearings regrettably fails to use an opportunity to perforn an important educative function. Not only are police not disciplined by the courts when evidence is suppressed, but the officer may actually receive support from his brother officers for losing a good case on a technicality. Internal disciplinary proceedings, however, if properly utilized, can liave an effective educative impact because the officer is punished directly by his

355. See Clarke, A Federal Prosecutor Looks at the Civil Rights Statutes, 47 Colum. L. REv. $175,179-81$ (1947).

356. 18 U.S.C. $\S 242(1976)$.

357. 18 U.S.C. $\$ 2234$ (1976).

358. 18 U.S.C. $\S 2235$ (1976).

359. 18 U.S.C. $§ 2236$ (1976).

360. See Screws v. United States, 325 U.S. 91, 101-05 (1945).

361. See generally Edwards, Criminal Liability for Unreasonable Searches and Seizures, 41 VA. L. REv, 621 (1955).

362. After such cases as Council of Organizations on Philadelphia Police Accountability and Responsibility v. Rizzo, 357 F. Supp. 1289 (E.D. Pa. 1973), criminal prosecutions are unlikely; and in any event, given the dual role of the district attorney's staff, such prosecutions are an unsatisfactory vehicle for vindication of the rights involved. Id. at 1320.

363. See Sevilla, Exclusionary Rule and Police Perjury, 11 SAN Diego L. Rev. 839, 877-78 (1974). 
superiors with whom he does not have the same value conflicts as he does with the courts. However, the American Bar Association Standards Relating to the Urban Police Function has pointed out some of the glaring problems with disciplinary proceedimgs:

(1) internal investigations against individual or widespread inisconduct are rarely effective on a continuous basis;

(2) there is generally unwillingness annong officers to complain about or testify as to the misconduct of other officers;

(3) few departments have adequate procedures for receiving and investigating citizen complaints;

(4) few departments have adequate hearing procedures or disciplinary policies which ensure fairness for all parties; and

(5) most departments liandle internal disciplinary matters in secrecy, thus creating concern about whether complaints are liandled fairly. ${ }^{364}$

Thus, considerable disagreement and skepticism exist about whether internal disciplinary proceedings are an effective alternative remedy. ${ }^{365}$ In addition to internal proceedings, there have been attempts at external review either by civilian review boards, the most notable one being in Philadelphia, or by ad hoc groups. ${ }^{366}$ Unfortunately, these attempts have never lived up to their expectations. ${ }^{367}$ Attempts by courts to compel the implementation of police disciplinary systems have also been unsuccessful. ${ }^{368}$ OSHA, however, may be im a better position to fornulate an effective internal disciplinary system. If it can articulate proper standards and convince both the OSHRC and the courts that it is vigorously enforcing such a system, the potential exists for using such a system, probably in conjunction with existing civil and criminal sanctions, as a suitable alternative to the exclusionary rule.

The final alternative to the exclusionary rule is injunctive relief. ${ }^{369}$

364. aba Project on Standards for Criminal Justice: Standards Relatino to the URBAN POLICE Function $\S 5.3$, Comment b, at 159 (Approved Draft 1973) (listing findings of PRESIDENT'S COMMISSION ON LAW ENFORCEMENT AND ADMINISTRATION OF Justice, Task ForCE RePORT: THE POLICE, 193-97 (1967)).

365. See, e.g., Goldstein, Administrative Problems in Controlling the Exercise of Police Authority, 58 J. CRIM. L.C. \& P.S. 160 (1967); cf. Quinn, The Effect of Police Rulemaking on the Scope of the Fourth Amendment Rights, 52 J. URB. L. 25 (1974) (supporting promulgation of police rulemaking to establish a systein of police procedure).

366. See Comment, Police-Philadelphia's Police Advisory Board-A New Concept in Community Relations, 7 ViLL. L. Rev. 656 (1962).

367. See Note, The Administration of Complaints by Civilians Against the Police, 77 HARv. L. REv. 499 (1964).

368. See, e.g., Rizzo v. Goode, 423 U.S. 362 (1976); ef. Calvin v. Conlisk, 367 F. Supp. 476 (N.D. Ill. 1973) (court would not inject itself imto management and administration of police department to cure an imeffective disciplinary system because the controversy was not justiciable).

369. See generally Note, The Federal Injunction as a Remedy for Unconstitutional Police Conduct, 78 YALE L.J. 143 (1968). 
The Civil Rights Act of $1871^{370}$ provides for equitable relief, including injunctive decrees. ${ }^{371}$ As a practical inatter, an einployer seeking such relief will probably encounter soine difficulty with equitable inaxims, such as "clean hands," 372 when he has engaged in conduct violating the Act. The requireinent that the legal remedy be inadequate ${ }^{373}$ is not a problein because it is unlikely that damages can adequately reinedy a fourtl ainendment violation. ${ }^{374}$ In a curious reversal, OSHA may invoke the nnaxim that equity will not interfere with pending criminal proceedings, ${ }^{375}$ but this arguinent contradicts OSHA's separate contention that its proceedings are civil. Injunctive relief also has limited potential as an effective alternative in the OSHA sphere. There are difficulties in drafting a sufficiently specific order and obvious feasibility problems if courts have to inonitor day-to-day OSHA operations to insure compliance. ${ }^{376}$ Further, the federal courts would be wary of attempting to interfere via injunction with the internal structure of an executive enforcement agency. ${ }^{377}$

Thus, pursuant to the general rule that federal agencies are not, in the absence of statutory mandate to the contrary, required to comply with technical rules of evidence, ${ }^{378}$ the OSHRC inust engage in a costbenefit analysis of the exclusionary rule to determine whether the sanction should apply to its proceedings. This analysis slould consider the existence of effective alternative remedies. If the courts determine that the OSHRC does not have to apply the exclusionary rule as a inatter of law, the OSHRC should decide the issue based on policy considerations. This task is particularly formidable for the OSHRC because of the inagnitude of the coinpeting interests: the einployer's right to privacy guaranteed by the fourth amendment versus the administrative and statutory policy to protect and proinote worker safety and liealth.

370. 42 U.S.C. § 1983 (1976).

371. See, eg., Lankford v. Gelston, 364 F.2d 197 (4th Cir. 1966). See also Hague v. CIO, 307 U.S. 496 (1939).

372. See generally Society of Good Neighbors v. Van Antwerp, 324 Mich. 22, 36 N.W.2d 308 (1949).

373. See Gomez v. Layton, 394 F.2d 764, 766 (D.C. Cir. 1968).

374. See Siedel, Injunctive Relief for Police Misconduct in the United States, 50 J. URB. L. 681, 691-93 (1973).

375. See Younger v. Harris, 401 U.S. 37, 42 (1971).

376. See Lewis v. Kugler, 446 F.2d 1343 (3d Cir. 1971).

377. See generally Long v. District of Columbia, 469 F.2d 927 (1972).

378. See Opp Cotton Mills, Inc. v. Administrator of the Wage and Hour Div., 312 U.S. 126, 155 (1941). 


\section{CONCLUSION}

The exclusionary rule has survived intense legal controversy including predictions by inembers of the Supreine Court that the rule faces extinction. Debate swirls about whether the rule should remain inflexible in pursuit of its noble purposes; or whether the rule should be modified to increase its efficacy, curtail its dysfunctions, and silence its critics; or finally whether the rule should be abandoned entirely. A single cure is often unsuited to remedy a multitude of evils, and in this respect the exclusionary rule was destined from its inception to encounter criticism. While the sanction has not proved to be the coinplete corrective its proponents had hoped it would be, it is hardly the bane that its detractors depict.

The rule inay be fairly criticized for attemptimg to do justice incidentally and for enforcing penalties indirectly, while exacting a high political price in the process. Also, it is certainly not propitious that the exclusionary rule is inerely the least ineffective of the alternative sanctions. Much of the criticisin presently directed at the exclusionary rule should more properly be directed at the coinphicated and abstruse substantive fourth amendment law that the sanction seeks to enforce. In the criminal sphere the search and seizure law is an amalgain of paradoxes rendering it extreinely difficult for the average law enforcement officer to know its limits with certainty. Administrative search law has far fewer intricacies and vicissitudes than criminal search law; the latter inust contend with diverse probleins ranging from searches of automobiles to searches incident to apprehensions, while the former requires only that comphiance officers master the law of administrative search warrants. Requiring comphance officers to inaintain a high level of proficiency in this limited area, utilizing the exclusionary sanction as an induceinent, would not result in the forfeiture of the governinent's legitimate interest in enforcing OSHA. The extension of the exclusionary rule to OSHRC liearings could result in a sufficient stimulus to compliance officers to sustain their professionalisin and could resuscitate a beleaguered fourth ainendinent. 